\title{
Scaffolding Strategies for Tissue Engineering and Regenerative Medicine Applications
}

\author{
Sandra Pina ${ }^{1,2, *}$, Viviana P. Ribeiro ${ }^{1,2}$, Catarina F. Marques ${ }^{1,2} \mathbb{D}$, F. Raquel Maia ${ }^{1,2,3}$, \\ Tiago H. Silva ${ }^{1,2} \mathbb{D}_{\text {, Rui L. Reis }}{ }^{1,2,3}$ and J. Miguel Oliveira 1,2,3
}

1 3B's Research Group, I3Bs-Research Institute on Biomaterials, Biodegradables and Biomimetics, University of Minho, Headquarters of the European Institute of Excellence on Tissue Engineering and Regenerative Medicine, AvePark, Parque de Ciência e Tecnologia, Zona Industrial da Gandra, 4805-017 Barco, Guimarães, Portugal; viviana.ribeiro@i3bs.uminho.pt (V.P.R.); catarina.marques@i3bs.uminho.pt (C.F.M.); raquel.maia@i3bs.uminho.pt (F.R.M.); tiago.silva@i3bs.uminho.pt (T.H.S.); rgreis@i3bs.uminho.pt (R.L.R.); miguel.oliveira@i3bs.uminho.pt (J.M.O.)

2 ICVS/3B's—PT Government Associate Laboratory, 4805-017 Braga/Guimarães, Portugal

3 The Discoveries Centre for Regenerative and Precision Medicine, Headquarters at University of Minho, Avepark, 4805-017 Barco, Guimarães, Portugal

* Correspondence: sandra.pina@i3bs.uminho.pt; Tel.: +351-253-510933

Received: 10 May 2019; Accepted: 3 June 2019; Published: 5 June 2019

\begin{abstract}
During the past two decades, tissue engineering and the regenerative medicine field have invested in the regeneration and reconstruction of pathologically altered tissues, such as cartilage, bone, skin, heart valves, nerves and tendons, and many others. The 3D structured scaffolds and hydrogels alone or combined with bioactive molecules or genes and cells are able to guide the development of functional engineered tissues, and provide mechanical support during in vivo implantation. Naturally derived and synthetic polymers, bioresorbable inorganic materials, and respective hybrids, and decellularized tissue have been considered as scaffolding biomaterials, owing to their boosted structural, mechanical, and biological properties. A diversity of biomaterials, current treatment strategies, and emergent technologies used for 3D scaffolds and hydrogel processing, and the tissue-specific considerations for scaffolding for Tissue engineering (TE) purposes are herein highlighted and discussed in depth. The newest procedures focusing on the 3D behavior and multi-cellular interactions of native tissues for further use for in vitro model processing are also outlined. Completed and ongoing preclinical research trials for TE applications using scaffolds and hydrogels, challenges, and future prospects of research in the regenerative medicine field are also presented.
\end{abstract}

Keywords: biomaterials; biopolymers; inorganic materials; scaffolds; hydrogels; porous structures; bioprinting; regenerative medicine; tissue engineering

\section{Introduction}

Tissue engineering (TE) and regenerative medicine (TERM) have arisen as new biomedical fields that bring advanced approaches for damaged tissue regeneration and healing [1]. The field of TERM has significantly increased over the past decades, and its advances have involved a multitude of research, including biomaterials design and processing, surface characterization, and functionalization for improved cell-material interactions and imaging. Diverse approaches proposed include: (i) direct implantation into the defects of cells isolated from the patient [2]; (ii) bioactive molecules and growth factor delivery targeting tissue specificity [3]; (iii) cell-free scaffolding biomaterials [4]; and (iv) cell-laden scaffolding structures mimicking the natural extracellular matrix $(\mathrm{ECM})$ of the tissues $[5,6]$. 
The latter ones are the most commonly used, which typically involve three-dimensional (3D) porous and hydrogels scaffolds, on which the cells grow and organize to form an ECM used in the regenerative process [5]. These 3D constructs deliver the physicochemical and mechanical maintenance for in vitro ECM formation, being slowly degraded, resorbed, or metabolized upon in vivo implantation $[7,8]$. The porosity, pore sizes, and interconnectivity of these structures hold a direct influence over their functionality. High porosity is important for allowing cell infiltration and ECM colonization, which is also directly influenced by pore size. Open and interconnected pores will benefit the growth, proliferation, and migration of the cells to an extent on ECM production. Additionally, the tissue vascularization and formation of new tissue may be faster [9]. On the other hand, the microporosity is also required for efficient cell adhesion and spreading, as well as for facilitating the initial mechanical strength between the scaffold and the tissue $[10,11]$. The degradation, biocompatibility, safety, stability, and cost-efficiency are also important considerations for clinical scenarios [12,13].

A broad variety of naturally derived and synthetic-based polymers have been applied for scaffold processing. The natural polymers have been showing biological properties that better fit to the regular microenvironment of tissues, promoting desirable cellular responses, biocompatibility, and degradability [14]. More recently, materials derived from decellularized ECM (dECM) have been widely explored in TERM. In fact, dECM preserves the native tissue composition, not only in terms of structural proteins as collagen, but also preserves growth factors and cytokines, which can improve cell growth and viability, and tissue repair and remodeling [15]. Further, dECM has been obtained by means of employing different processing methodologies and from a diversity of tissues, such as bone, cartilage, meniscus, tendons, skin and adipose tissue, urinary bladder, small intestinal submucosa, liver, and brain [16-21]. On the other hand, the lack of mechanical properties of those biomaterials can be overcome by means of using synthetic-based polymers or combining them with inorganic and ceramic materials to form composite structures with superior strength, osteoconductivity, and bioresorbability [22-24]. Using synthetic polymers can also improve the chemical stability and the micro and nano-structural features of the scaffolds, which positively affect the cell adhesion, spreading, growth, and ECM infiltration [25]. Thus, depending on the TERM strategy, different biomaterials and processing technologies should be considered in order to optimize the scaffold's performance in terms of surface morphology and internal configuration. The most promising technologies proposed for scaffold processing include, among others, solvent casting with particulate leaching [26], freeze-drying [27], gas foaming [28], fiber bonding and electrospinning [29], phase separation [30], and more advanced technologies, such as 3D printing methodologies [31-33]. All of them have a great impact on mimicking human tissues for regeneration when combating chronic and degenerative diseases [34]. Nowadays, the field of TE has been revolutionized by the application of such technologies for developing bio-inspired models of complex tissue diseases for novel therapeutic drug screening and specific biomarker identification in patient-specific theranostic approaches [35]. Several studies have focused on the 3D character and multi-cellular interactions of native tissues, envisioning these 3D technologies as ideal for TERM in vitro model processing. The superior complexity and hierarchy of 3D engineered models have proved to better mimic the natural ECM of damaged tissues, simulating interactions between healthy-unhealthy cell types and the influence of the physical microstructure and mechanical properties of the native tissues [36]. Thus, the biomaterials, approaches, and emerging technologies applied for 3D scaffolds and processing of hydrogel matrices according to the final TERM application and native tissue complexity are herein presented. The multifunctional scaffolds with more complex biological functions and their usefulness for different TERM strategies are also explored. Clinical trials involving 3D scaffolds and hydrogel matrices, challenges, and future prospects of research in the TERM field are also underlined.

\section{Biomaterials for Tissue Engineering and Regenerative Medicine}

Current strategies for TERM involve the use of a wide pallet of materials, consisting of natural and synthetic polymers (e.g., proteins, polysaccharides glycosaminoglycans, poly-glycolic acid (PLG), 
polyl-actic acid (PLA), poly- $\varepsilon$-caprolactone (PCL), etc.), inorganic biomaterials, which include metals (e.g., titanium and its alloys, etc.) and ceramics (e.g., alumina, zirconia, CaPs, calcium phosphate cements (CPCs), etc.), and their hybrid combinations. Polymers have great stiffness and advantages are added to the natural polymers, namely from their similarity with the ECM, specific degradation owing to the susceptibility of the enzyme action, and improved recognition by the living body. Inorganic biomaterials are recognized for their biocompatibility, osteoconductivity and bioresorbability. The most promising polymers and inorganic biomaterials, as well as their hybrids, are described as follows.

\subsection{Natural and Synthetic Polymers}

Natural and synthetic polymeric materials are popular for engineering and regenerating hard and soft tissues due to their vast diversity of properties, such as biodegradation, mechanical properties, high porosity and surface-to-volume ratio, as well as small pore size [22,23,37]. Multiple applications for different type of polymers have been exploited in the current market for bone, cartilage, skin, wound healing vascular grafts, and tracheal splints $[38,39]$.

Natural polymers obtained from renewable resources, such as algae, plant, animal, and microorganisms, are similar to biological macromolecules, and easily recognized by the environment (Figure 1) [40]. Owing to their similarity with the ECM, natural polymers, also known as biopolymers, may also elude chronic inflammation toxicity or immunological reactions, frequently noticed with synthetic polymers. Therefore, these types of polymers are crucial for designing therapeutic systems to be used as bioactive compounds and drug delivery systems for disease treatment, or even to bioengineer functional tissues. Biopolymers that have been clinically used for implant fabrication include proteins (e.g., silk fibroin, collagen, gelatin, keratin, fibrinogen, elastin, and actin), polysaccharides (e.g., chitosan, chitin, alginate, gellan gum, and derivatives), and glycosaminoglycans (e.g., hyaluronic acid) [40]. Structural proteins, such as elastin, fibrin, silk, and albumin, have been applied as sutures for scaffolds fabrication and as drug delivery systems [41,42].
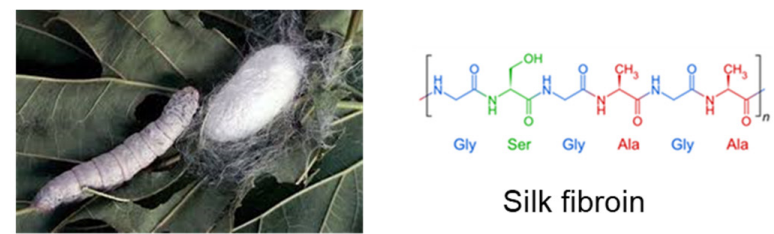

Silk fibroin
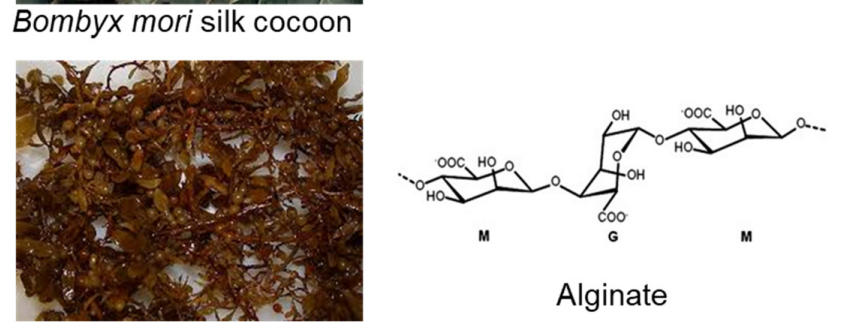

Brown algae

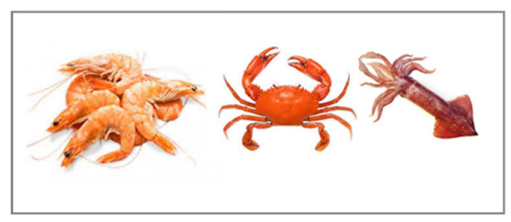

Shrimp, crab and squid

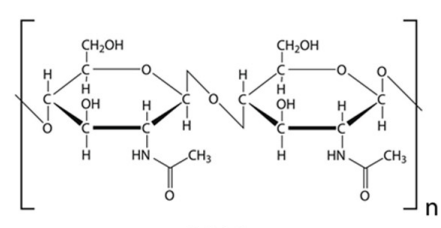

Chitin

Figure 1. Some biopolymers derived from renewable resources and respective chemical structures: silk fibroin, alginate, and chitin.

Synthetic polymers, on the other hand, have excellent processing characteristics in terms of their molecular weight, degradation, and mechanical properties, with the advantage of having tailored property profiles for specific applications [43]. Hydrolytically degradable polymers are mostly chosen as implants due to their minimal site and patient-to-patient variations when compared to enzymatically 
degradable polymers [44]. However, many of these polymers present an immune response or toxicity, particularly when combined with certain polymers and not being capable of being incorporated with host tissues [45]. A strategy is to develop hybrid materials by combining them with natural polymers to improve hydrophilicity, cell attachment, and biodegradability. The most-used synthetic polymers in TE are polyglycolide (or poly glycol acid (PGA)), polylactide (or PLA), poly-lactide-co-glycolide (PLGA), poly-(D,L-lactic acid) (PDLLA), poly-ethylene-glycol (PEG), and PCL. These polymers can be self-reinforced to enhance their mechanical strength [46].

\subsection{Inorganic Biomaterials}

An assortment of natural and synthetic inorganic biomaterials (metallic and ceramics) with particular compositions, microstructures, and long-term reproducibility have been proposed to repair or substitute diseased and damaged parts of the musculoskeletal system and periodontal anomalies (Figure 2). These types of biomaterials have been established for orthopedic load-bearing coatings (hip acetabular cups), bone grafting and cements, and dental restorations [47]. Metallic biomaterials (e.g., titanium and its alloys) possess high strength, low modulus of elasticity, and low density, while ceramics biomaterials, also known as bioceramics (e.g., alumina, zirconia, CaPs, calcium phosphate cements (CPCs), and silicates), are considered for their biocompatibility, osteoconductivity, and osteogenic capacity (Figure 2A-C) [48,49].

Inorganic biomaterials can be classified as bioinert, bioactive, or bioresorbable depending on their ability to bond directly with native tissues once implanted. Bioinert materials (e.g., alumina, zirconia, titanium, and its alloys) have no interaction with their adjacent tissue after implantation, typically being applied as structural-support implants, such as bone devices and femoral heads. On the other hand, bioactive materials (e.g., bioglasses and glass-ceramics) bond directly with living tissues, and have been applied to fill small bone defects and periodontal irregularities. Bioresorbable materials (e.g., CaPs, CPCs, and calcium carbonates or calcium silicates) gradually absorbed in vivo and are replaced by bone over time.

Naturally-derived inorganic biomaterials from marine shells, corals, sponges, nacres, and animal (fish and chicken) bones offer an abundant source of calcium compounds (e.g., calcium carbonate and calcium phosphate) for TERM applications (Figure 2D) [50]. Coral-derived materials have been used as raw materials to obtain CaPs-based biomaterials for bone tissue repair and regeneration, owing to their microstructural and mechanical properties. Our group has been involved in the production of porous bioceramics using a variety of red algae (e.g., Coralline officinallis) [51,52]. This process involves a thermal and chemical treatment to convert calcium carbonate skeletons of $C$. officinallis particulates into CaPs with hydroxyapatite (HAp) nanocrystallites, while keeping the natural microstructure of the red algae [51].

Synthetic inorganic biomaterials, such as alumina and zirconia, bioactive glasses and glass-ceramics, and CaPs-based materials (e.g., sintered, coatings and cement pastes), are the ones commonly applied in TERM $[53,54]$. These biomaterials can be obtained by numerous methods (e.g., aqueous precipitation, hydrolysis, sol-gel synthesis, hydrothermal synthesis, mechanochemical synthesis, microwave processing, and spray drying), resulting in materials with increased crystal size and morphology [55-57]. Among them, the wet precipitation method offers an advantage on the material synthesis, which involves a precise control of the $\mathrm{pH}$, temperature, particle morphologies, and the presence of additives [58].

A number of studies are dedicated to functionalizing bioactive inorganic materials by doping them with ionic elements (e.g., strontium, zinc, magnesium, manganese, silicon) that are slowly released during bone resorption, and therefore can boost biocompatibility and the mechanical strength of the implants [59-64]. Moreover, these minerals afford physicochemical modifications, thus accelerating bone formation and resorption in vivo $[65,66]$. 

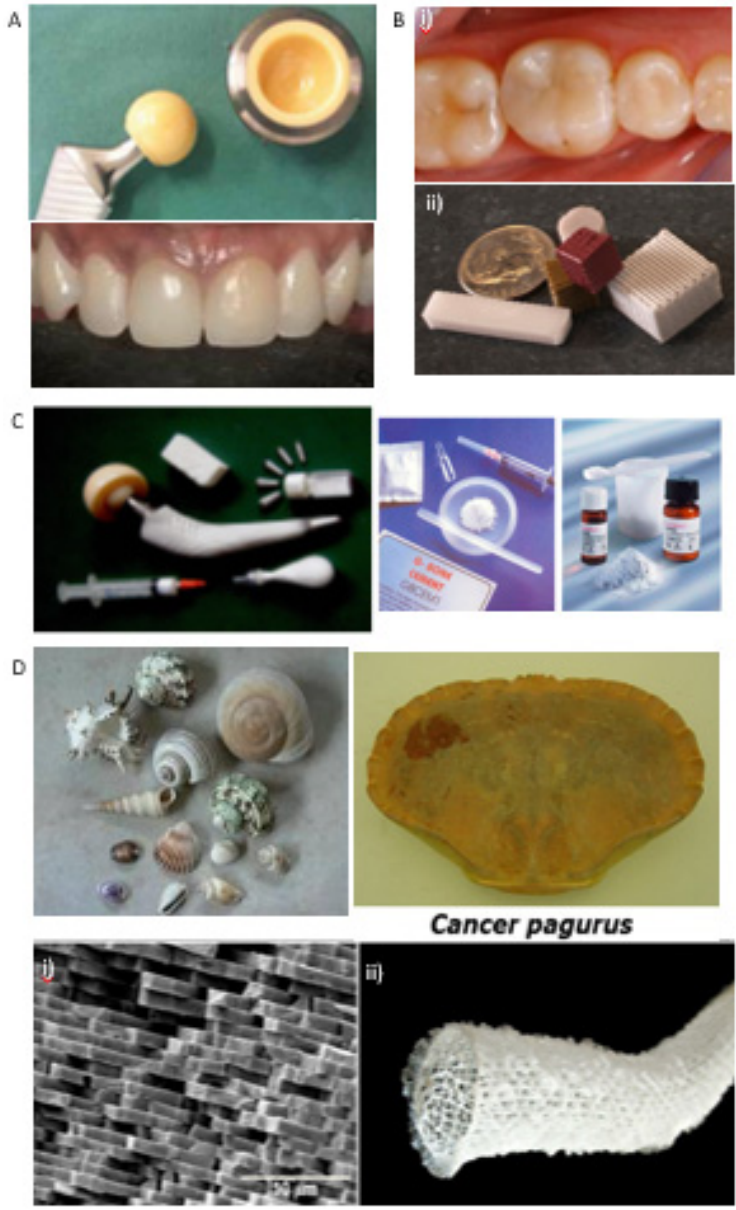

Figure 2. (A) Alumina/zirconia bioceramics for hip joint prosthesis and dentistry [67,68]; (B) (i) Bioactive glass-ceramics for dental applications and (ii) robocast glass scaffolds produced by scientists at Missouri University of Science and Technology [69,70]; (C) CaPs-based bone graft materials, such as porous blocks, powders and granules, hydroxyapatite (HAp) coating on a femoral metal stem, and self-setting CPC pastes that can be injected into the bone defect. Adapted from previous studies [71,72] with permission. (D) Images of marine organisms, namely shells, corals, sponges, and nacres, and microstructure image of the nacre structure, evidencing the plate-like aragonite crystals (i) and glass sponge (ii). Reprinted from a previous study [50] with permission.

\subsection{Organic-Inorganic Hybrid Biomaterials}

Hybrid biomaterials formed by combining organic and inorganic compounds result in multifunctional materials with tailored mechanical, thermal, and structural stability properties [73]. Concerning the fabrication of composite scaffolds, it is essential above all to attain a good compatibility between the phases and maintain the porous structure and the mechanical strength of the scaffolds [74,75]. Furthermore, nanostructured hybrids have also been preferred due to the nanosized features of the fillers, thus enhancing the bonding capacity of the tissue to the organic matrices that the individual materials cannot accomplish [76]. The nanoparticles have large surface areas when compared to the micro-sized fillers, thus contributing to upgraded mechanical properties, while retaining the biocompatibility and osteoconductivity, cell adhesion, and proliferation of the fillers $[77,78]$.

Many combinations of polymers and inorganic materials have been proposed to engineer different tissues with enhanced osteoconductivity and mechanical properties, including polymers of natural origins (collagen, gelatin, silk, chitosan, alginate, hyaluronic acid, and gellan gum), synthetic polymers 
(e.g., PEG, PLA, PGA, PLGA and PCL), and bioceramics, silicates, bioactive glasses, and carbon nanotubes [79-86].

\section{Scaffolding Strategies for Tissue Engineering and Regeneration}

Recently, the approaches used in TERM have mainly been committed to 3D porous scaffolds and hydrogels, resulting in mechanically stable structures with controlled degradation rates and porosity for the transport of gases, nutrients, and regulatory factors.

A number of traditional technological approaches categorized into the foam replica method, particulate-leaching, freeze drying, gas foaming, and phase separation, have been applied for scaffold production, showing inexpensive and optimized physicochemical property structures. Lately, advanced manufacturing (e.g., 3D printing and robocasting), supercritical fluid technology, and microfluidics have emerged to produce complex structures for defective tissue regeneration, with boosted porosity, structural and mechanical properties, and cellular adhesion, providing several advantages over the conventional ones.

A description of 3D porous scaffolds and hydrogel strategies is provided below.

\subsection{D Porous Scaffolds}

With the increasing need for advanced therapeutics for TERM, 3D scaffolds arise as porous matrices capable of providing a proper microenvironment for such purposes. The scaffolds should allow: (i) the transport of the nutrients needed to the cell attachment, proliferation, and differentiation; (ii) stimulation of cell-biomaterial attachment, growth, and migration; (iii) mechanical support; and (iv) a controlled degradation rate with no toxicity or inflammation risk to the cells [87].

As mentioned previously, different technologies and biomaterials have been applied in order to fabricate porous scaffolds with organized porosity and pore sizes, such as foam replicas, freeze-drying, phase separation, particulate-leaching, gas foaming, photolithography, microfluidics, supercritical fluid technology, stereolithography, robocasting, and 3D printing and bioprinting [81,88-99].

\subsubsection{Natural 3D Porous Scaffolds}

Over the past years, our group has been involved in the fabrication of 3D porous scaffolds for hard TE applications, mainly using materials of natural origin [53,100-104]. In particular, the use of marine resources are an alternative to extract bioactive compounds, with which resources are isolated from by-products at low cost, thus creating value from products that are considered waste for the fish transformation industry. In a study by Diogo et al. [105], the fabrication of 3D scaffolds is reported using collagen from shark skin (Prionace glauca) combined with CaPs obtained from the teeth of two different shark species (Prionace glauca and Isurus oxyrinchus) through freeze-drying technique (Figure 3A). The produced scaffolds showed a homogeneous distribution of apatite particles throughout the collagen matrix able to support the attachment and proliferation of osteoblast-like cells (Figure 3B,C) [105].

In another study from our group, the development of biofunctional scaffolds was reported using a natural biopolymer containing silk fibroin (SF) and $\beta$-tricalcium phosphate $(\beta-\mathrm{TCP})$ and incorporating strontium, zinc, and manganese via salt-leaching and a freeze-drying technique [64]. The scaffolds revealed highly interconnected macroporosity of $500 \mu \mathrm{m}$, and a microporous structure with a size range of 1-10 $\mu \mathrm{m}$ (Figure $4 \mathrm{~A}$ ). The scaffolds presented biomineralized globule-like structures of apatite crystals and porous spherulite-like structures with the incorporation of the ceramic part into the silk upon immersion in simulated body fluid for 15 days (Figure 4B). Remarkably, in vitro assays conducted with these biomaterials and human adipose-derived stem cells (hASCs) have shown different responses in terms of cell proliferation and differentiation when varying the doping elements in the scaffolds (Figure 4C). The presence of $\mathrm{Zn}$ led to improved cell proliferation, while the Sr- and Mn-doped scaffolds presented higher osteogenic potential, as demonstrated by DNA quantification and alkaline phosphatase (ALP) activity, respectively. The combination of $\mathrm{Sr}$ with $\mathrm{Zn}$ led to a significant influence on cell proliferation and osteogenesis in comparison to the single ions. Several studies have been reported using dECM-based scaffolds for TERM [17-19,106,107]. In fact, those types of scaffolds confer 
an ideal microenvironment, with instructive biological molecules and reduced immuno responses [108]. For example, Zhang et al. [17] prepared dECM from swine menisci together with gelatin/chitosan composite scaffolds, with enhanced elastic modulus and non-cytotoxicity properties for meniscus TE. The dECM-based scaffolds improved rat bone marrow stem cells (BMSC) proliferation when compared with scaffolds without dECM. In another study, Parmaksiz et al. [19] developed a multilayer scaffold of decellularized bovine small intestinal submucosa (bSIS) layers, together with HAp microparticles and PCL, with potential for bone TE. For that, bSIS layers were stacked with PCL solutions that acted as a glue, in order to improve the mechanical properties. Then, the multilayered PCL/bSIS scaffold was uniformly composited with $\sim 30 \mu \mathrm{m}$ HAp microparticles in the structure. In vitro studies have shown that rat BMSCs proliferated and differentiated along the osteoblastic lineage on the scaffolds within 21 days. Furthermore, the cell-laden scaffold revealed a maximum strength after 21 days of culture, close to the values of the cell-free multilayered scaffolds in wet conditions.

A

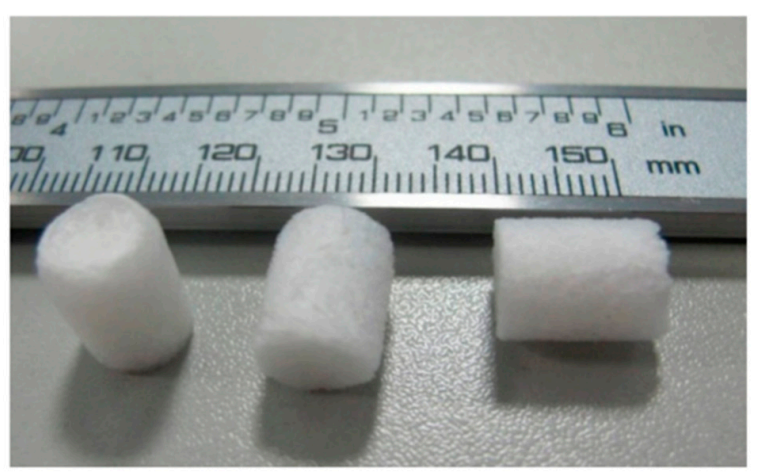

B

X-ray 2D projection
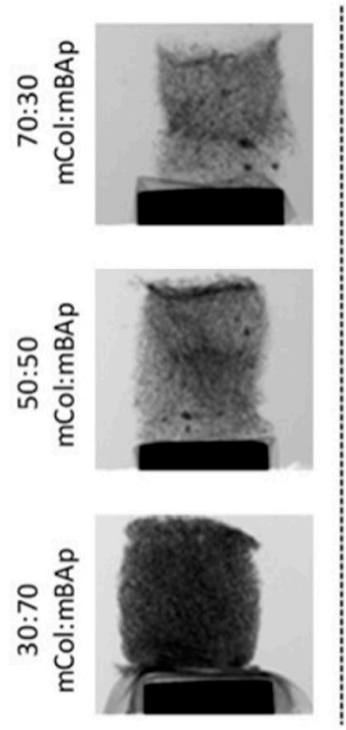

C

3D Reconstruction

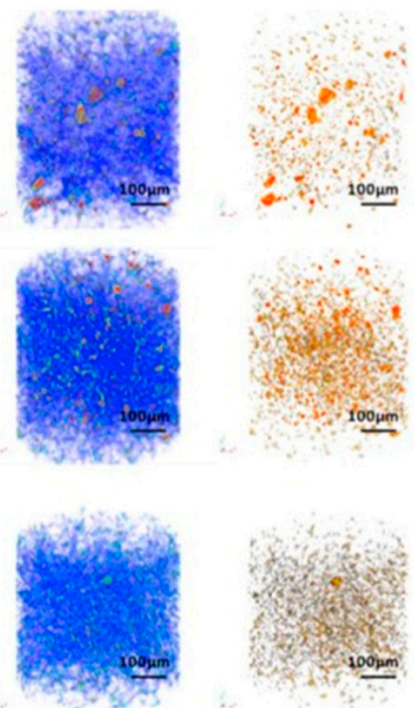

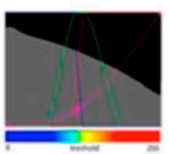

Figure 3. (A) Scaffolds of marine collagen: marine biopatite particles composite. Representative images of 12.5\% 1-[3-(dimethylamino)propyl]-3-ethylcarbodiimide hydrochloride/N-Hydroxysuccinimide (EDC/NHS) crosslinked scaffolds obtained by microcomputed tomography (micro-CT). (B) X-ray 2D projection and respective (C) 3D reconstruction of acquired structures, in which the first column shows a reconstruction of both polymeric and ceramic phases, and the second column shows only the ceramic phase. Homogeneous distribution of the materials is observed, according to a color scale: blue $=$ soft material (marine collagen); brown $=$ hard material (marine biopatite particles). Adapted from a previous study [105] with permission. 
SF

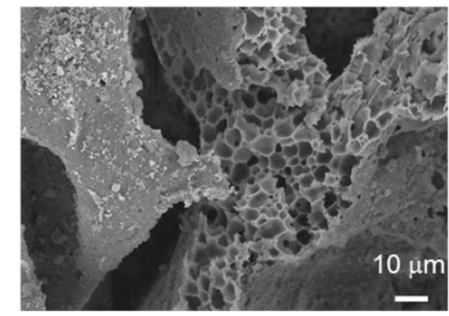

A

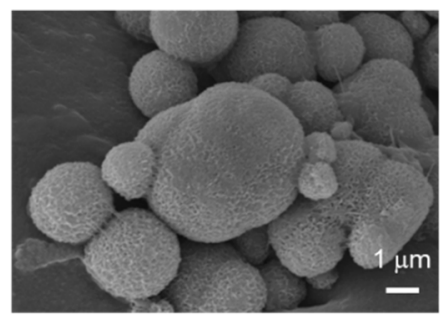

SF/TCP
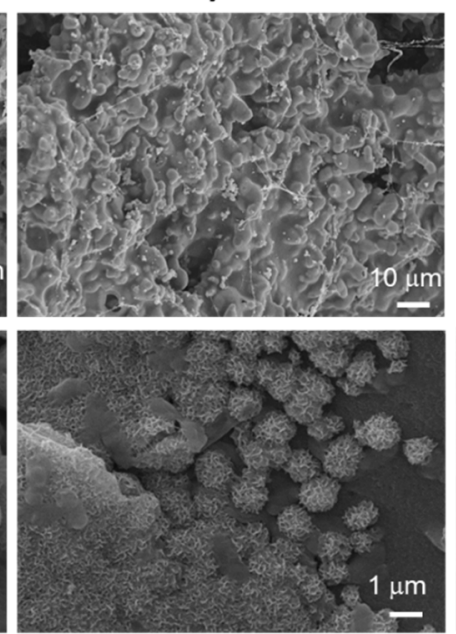

SF/ionic-doped TCP
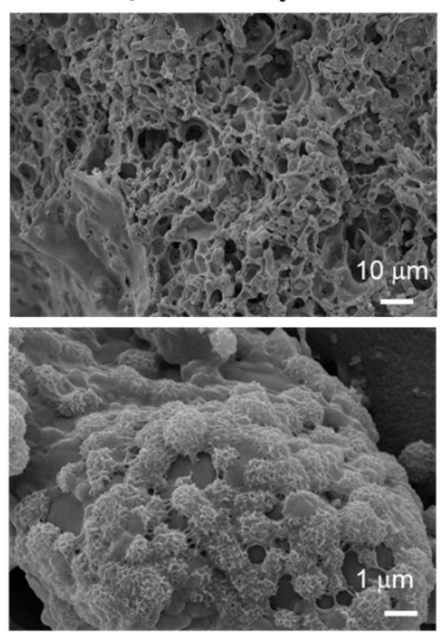
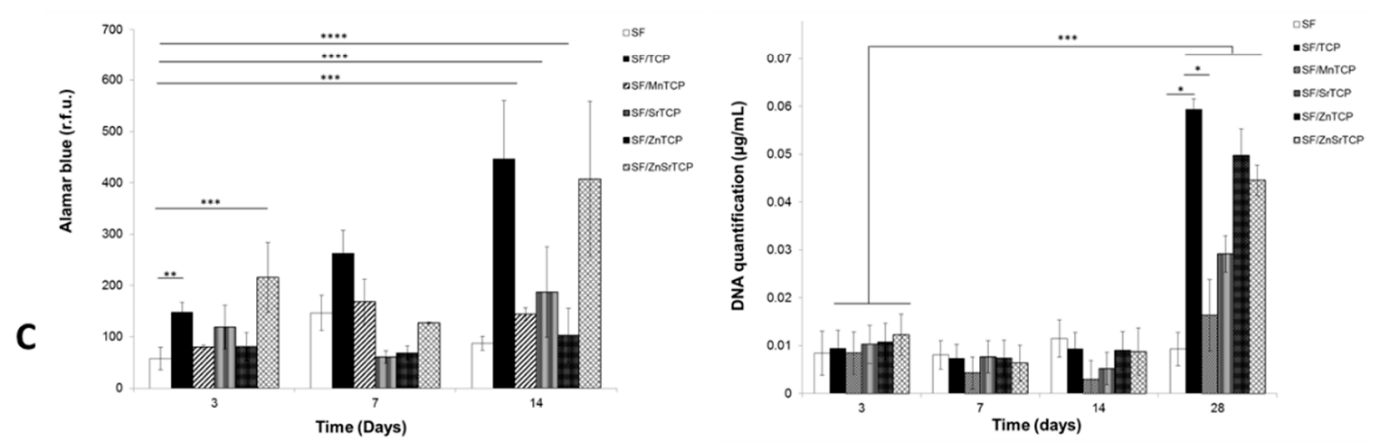

Figure 4. Scanning electron micrographs of silk fibroin (SF), SF/tricalcium phosphate (TCP), and SF/ionic-doped TCP scaffolds before (A) and after 15 days of mineralization (B). Viability and proliferation of the scaffolds seeded with human adipose-derived stem cells (hASCs): Alamar blue assay of hASCs cultured for 14 days (left), and DNA quantification at different time points (right) (C); * significant differences compared with SF and SF/Mn-doped TCP (MnTCP) and with SF/MnTCP and SF/Sr-doped TCP (SrTCP) $(\mathrm{p}<0.05) ;{ }^{* *}$ significant differences compared between SF and SF/TCP $(\mathrm{p}<0.005) ;{ }^{* * *}$ significant differences compared between $\mathrm{SF}$ at $3 \mathrm{~d}$ and the different compositions at $28 \mathrm{~d}(\mathrm{p}<0.0005) ;{ }^{* * * *}$ significant differences compared between with SF and SF/SrTCP and SF/ZnTCP $(\mathrm{p}<0.0001)$. Adapted from a previous study [64] with permission.

\subsubsection{D Printed Scaffolds}

The development of TE scaffolding for soft-to-hard tissue regeneration by additive manufacturing (AM) has been widely reported [109,110]. Among the available AM techniques, robocasting (also called direct-write assembly) is a versatile technique that allows the production of scaffolds with predefined morphologies and structures, capable of fully supporting their own weight during assembly, allowing precise control of pore size, shape, and alignment [111-113]. Miranda et al. [114] optimized the morphological properties of TCP powders by reducing the particle size and increasing the specific surface area for robocasting use. The $\beta$-TCP scaffolds were printed with various geometries in the range of $10-20 \mathrm{~mm} / \mathrm{s}$. Moreover, the compressive strength of the scaffolds achieved was 10-20 MPa, similar to the corresponding values for the cancellous bone (7-10 MPa). Additionally, Heo et al. [115] produced HAp/PCL composite scaffolds through robocasting technique with a well interconnected macroporosity yielding a final porosity of $73 \%$ and a pore size of $500 \mu \mathrm{m}$. The compressive modulus of the micro-HAp/PCL and nano-HAp/PCL scaffolds obtained was 1.3 and $3.2 \mathrm{MPa}$, respectively. The more hydrophilic surface of nano-HA/PCL, which resulted from the higher surface area of nano-size HAp, could promote better cell attachment and proliferation compared with micro-HAp/PCL. Martinez-Vazquez et al. [116] reported that the incorporation of PCL or PLA into $\beta$-TCP porous scaffolds, 
fabricated by robocasting, increased the compressive strength of the scaffolds. More recently, Marques et al. [117] studied pure and Sr- and Ag-doped biphasic CaPs scaffolds, obtained via robocasting, for bone tissue regeneration. The scaffolds showed different pore sizes with compressive strengths comparable to or even higher than that of cancellous bone. Moreover, the presence of $\mathrm{Sr}$ and $\mathrm{Ag}$ improved the mechanical strength and cell proliferation, and granted good antimicrobial activity against Staphylococcus aureus and Escherichia coli.

The incorporation of biomolecules in the scaffolds, such as growth factors, antibiotic, or anti-inflammatory drugs aimed at the acceleration of local bone healing, is currently under extensive research [118]. The robocasting technique is able to use a broad range of materials for the manufacture of scaffolds incorporating several biomolecules. Marques et al. [119] studied the processing conditions to obtain sintering-free composite scaffolds through robocasting (Figure 5), constituted by biphasic $\mathrm{CaP}$ (with $\mathrm{Ca} / \mathrm{P}$ ratio of 1.65 and 1.59), chitosan, and levofloxacin (LEV) in the absence of processing additives (dispersant and binders). After robotic deposition, the scaffolds maintained the shape and no filament collapsing could be observed (Figure 5A,B). However, the overlapping of scaffolds, with and without antibiotics, shows that they could not be totally superimposed, because the LEV modified the viscoelastic behavior of the inks (Figure 5C). The LEV-loaded scaffolds exhibited an early and fast drug release, but also presented bacteria growth inhibition ability, proving that the antibiotic was not degraded during the fabrication process. Furthermore, its bactericidal effectiveness was preserved, which opens a new path for local bone regeneration and infection treatments, since a more direct administration of a drug might be a better solution than the conventional treatment strategies. With the same purpose of including relevant biomolecules in the scaffolds, bioprinted scaffolds coated with dECM were developed $[107,120]$. Wu et al. [107] prepared calcium silicate (CS) and PCL scaffolds and then cultured an osteoblastic cell line (MG63) on top of the scaffolds in order to produce a relevant ECM coating for bone TE. Upon removal of the cellular content, human Wharton's Jelly mesenchymal stem cells (WJMSCs) were seeded on the scaffolds. In vivo studies using a rat critical defect were then performed. In turn, Kim et al. [120] developed PCL/ $\beta$-TCP scaffolds and then immersed the scaffolds in a porcine bone dECM solution. After lyophilization, pre-osteoblastic cells (MC3T3-E1 cell line) were cultured onto the scaffolds, and in vivo studies were evaluated in a rabbit critical calvarial defect. In both studies, the printed scaffolds coated with dECM have been shown to enhance osteogenic differentiation in vitro, and the implantation of the scaffolds showed new bone formation, which validate the use of $\mathrm{dECM}$ in the improvement of scaffolds for bone TE.

Recently, the 3D bioprinting technique has been commonly used in TERM. This technique has the advantage of allowing high freedom for cell and biomolecule positioning in diverse biomaterials with predefined designs and geometries [121]. Alginate is one of the most used biopolymer for 3D cell printing because it forms a stable hydrogel in the presence of divalent cations (e.g., $\mathrm{Ca}^{2+}$ or $^{2} \mathrm{Ba}^{2+}$ ) by ionic crosslinking $[121,122]$. However, alginate-based bioinks have some disadvantages, namely their biological activity, since they do not provide mammalian cell-adhesive ligands [123]. This fact can be overcome by modifying the alginate surface with peptides, such as arginine-glycine-aspartate (RGD), to provide molecule binding sites for cell adhesion [124], for example by blending it with gelatin, which also allows the viscosity of the hydrogel to be altered to satisfy extrusion and printing criteria [125]. Another study investigated 3D bioprinting scaffolds for cartilage tissue by combining collagen type I or agarose (AG) with sodium alginate (SA) incorporated with chondrocytes [126]. The results showed that the addition of collagen or AG had a little impact on the gelling behaviour and can improve the mechanical strength when compared to SA alone. Furthermore, the presence of collagen facilitated cell adhesion, accelerated cell proliferation, and enhanced the expression of the cartilage specific genes, namely Acan, Sox9, and Col2a1 [126]. Also, Lee et al. [127] produced cell-laden collagen-based scaffolds using a dispensing system with tannic acid as a crosslinker. The cellular activities using MC3T3-E1 cells and the tannic acid crosslinking process revealed their capability of supporting high cell viability with reasonable biocompatibility of the developed scaffolds. In another study, Kim et al. [128] developed a new strategy to fabricate a $\alpha-\mathrm{TCP} /$ collagen cell-laden scaffold with pre-osteoblasts MC3T3-E1 cells 
for bone tissue repair. The results showed that the $\alpha-\mathrm{TCP} /$ collagen scaffolds had significantly higher cellular activities compared with those of the controls, including metabolic activity and mineralization, as well as good mechanical properties.

(A)
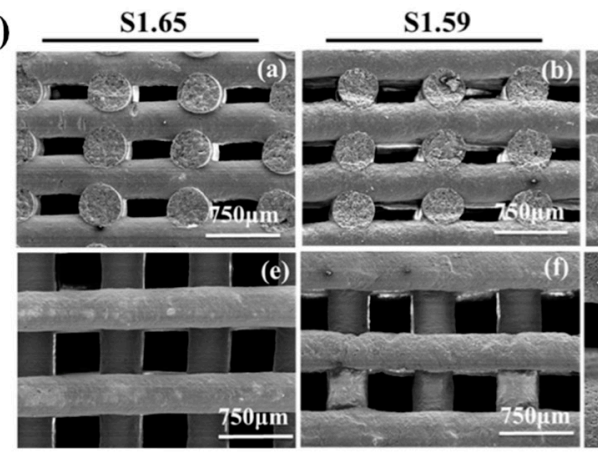

S1.65-LEV S1.59-LEV

(B)
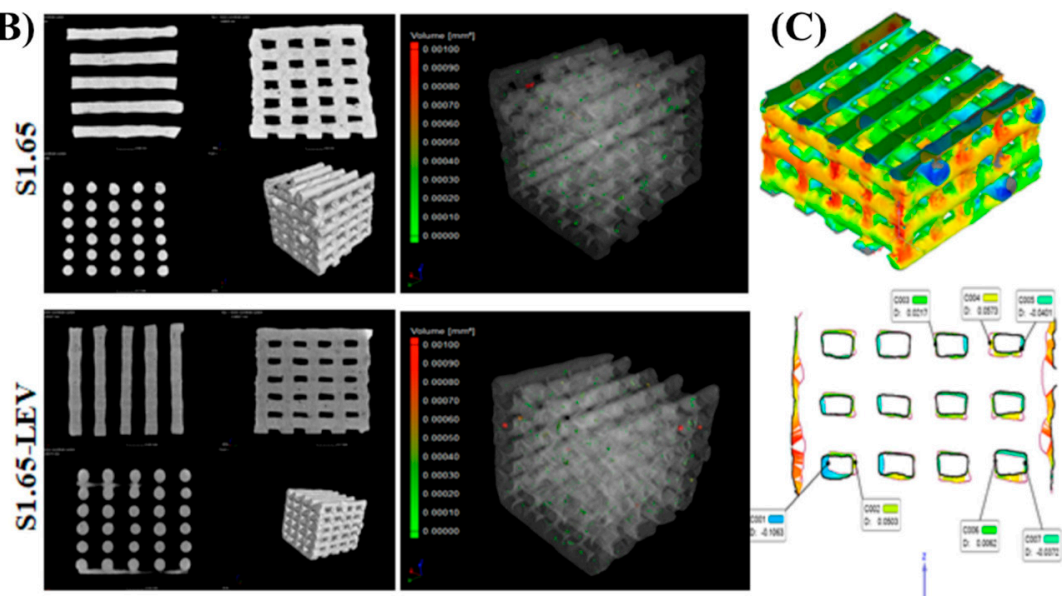

0.2000

0.1750
0.1500

0.1500
0.1250

0.1000
0.0750

0.0500

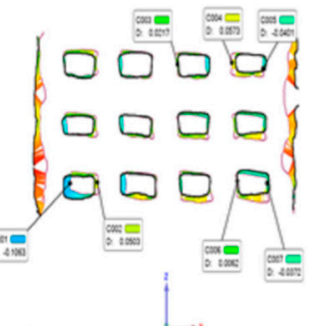
-0.0500
-0.0750
0.1000 -0.1000
-0.1250 $-0.1500$ -0.1750
-0.2000

Figure 5. (A) Scanning electron micrographs showing morphological aspects of $\mathrm{S} 1.65(\mathrm{Ca} / \mathrm{P}=1.65)$ and $\mathrm{S} 1.59(\mathrm{Ca} / \mathrm{P}=1.59)$ scaffolds with and without levofloxacin: $(\mathbf{a}-\mathbf{d})$ lateral views; $(\mathbf{e}, \mathbf{f})$ top-views; (g) filament detail, (h) pore detail; (B) 2D (top plane and cross-section views) and 3D images of S1.65 scaffolds with and without drug (levofloxacin) obtained through Metrology CT and 3D reconstruction of the scaffolds mapped with color-coded for the internal porosity of filaments. (C) The 3D and 2D views of overlapped S1.65 and S1.65- levofloxacin (LEV) mapped with color-coding. Adapted from a previous study [119] with permission.

Recent cellular and acellular reported studies using different scaffold strategies for TE purposes are summarized in Table 1. 
Table 1. The most recent studies of cellular and acellular 3D porous scaffold strategies for TE purposes.

\begin{tabular}{|c|c|c|c|c|c|}
\hline Technology & Materials & Cells/Growth Factors & Outcomes & Application & Ref. \\
\hline \multirow{7}{*}{$\begin{array}{l}\text { Freezing and } \\
\text { lyophilization }\end{array}$} & $\begin{array}{c}\text { Collagen }(\mathrm{Col}) / \text { carbon } \\
\text { nanotube }(\mathrm{CNT}) / \text { chitosan } \\
\text { (CS)/hydroxyapatite } \\
\text { (HAp) }\end{array}$ & - & $\begin{array}{l}\text { Increased hydrophilicity from } 87.8^{\circ} \text { to } 76.7^{\circ} \\
\text { and improved mechanical properties of the } \\
\text { composite scaffolds compared to Col }(211 \\
\mathrm{kPa}), \mathrm{CS}(284 \mathrm{kPa}), \mathrm{Col} / \mathrm{CNT}(311 \mathrm{kPa}) \text {, and } \\
\mathrm{Col} / \mathrm{CNT} / \mathrm{CS}(524 \mathrm{kPa}) \text { scaffolds }\end{array}$ & Bone tissue engineering & [129] \\
\hline & $\begin{array}{l}\text { Na-alginate } \\
\text { /hydroxyethylcellulose } \\
\text { /HAp }\end{array}$ & - & $\begin{array}{c}\text { After loading with Hap, the mechanical } \\
\text { properties of the scaffolds increased } \\
\text { deformation energy and rigidity gradient } \\
(19.44 \pm 0.85 \mathrm{~Pa}) \text {, with bioactivity and } \\
\text { biocompatibility in vitro and in vivo } \\
\text { (implanted in femur of adult male Wistar } \\
\text { rats for } 6 \text { weeks) }\end{array}$ & & [80] \\
\hline & $\begin{array}{l}\text { Collagen from shark skin/ } \\
\text { CaPs from shark teeth }\end{array}$ & Saos-2 cells seeding & $\begin{array}{c}\text { Use of EDC/NHS crosslinking increased the } \\
\text { attachment and proliferation of } \\
\text { osteoblast-like cells }\end{array}$ & & [82] \\
\hline & $\begin{array}{l}\text { Silk fibroin and } \\
\beta \text {-tricalcium phosphate } \\
\text { (TCP) }\end{array}$ & $\begin{array}{l}\text { Human adipose stem cells } \\
\text { (hASCs) seeded on the } \\
\text { scaffolds }\end{array}$ & $\begin{array}{l}\text { Highly interconnected macroporosity.; } \\
\text { significant responses of hASCs proliferation } \\
\text { and differentiation when varying the ionic } \\
\text { dopants in the scaffolds }\end{array}$ & & [64] \\
\hline & $\begin{array}{l}\text { Collagen and denatured } \\
\text { collagen (DCol) }\end{array}$ & $\begin{array}{l}\text { Rabbit chondrocytes } \\
\text { seeding }\end{array}$ & $\begin{array}{l}\text { Adhesion, proliferation, and } \\
\text { re-differentiation of chondrocytes by Col } \\
\text { scaffolds with triple helix and the } \\
\text { regeneration of cartilage defects, compared } \\
\text { with the DCol scaffolds }\end{array}$ & Cartilage tissue & {$[130]$} \\
\hline & $\begin{array}{l}\text { PLLA, PCL, and collagen } \\
\text { type I }\end{array}$ & $\begin{array}{l}\text { Adipose tissue-derived } \\
\text { mesenchymal stem cells } \\
\text { seeding }\end{array}$ & $\begin{array}{l}\text { Mechanically stronger mesh support, } \\
\text { provided by PCL-PLLA and cell adhesion, } \\
\text { and tissue formation promoted by the } \\
\text { collagen type I microsponges }\end{array}$ & Skin & {$[131]$} \\
\hline & Silk fibroin & - & $\begin{array}{c}\text { Elastic modules of the scaffolds between } 100 \\
\text { and } 900 \mathrm{kPa}\end{array}$ & n.d. & {$[132]$} \\
\hline
\end{tabular}


Table 1. Cont.

\begin{tabular}{|c|c|c|c|c|c|}
\hline Technology & Materials & Cells/Growth Factors & Outcomes & Application & Ref. \\
\hline & $\begin{array}{c}\text { Decellularized } \\
\text { extracellular matrix } \\
\text { (dECM)/gelatin/chitosan }\end{array}$ & rat BMSCs seeding & $\begin{array}{l}\text { Enhanced elastic modulus, no cytotoxicity, } \\
\text { and enhanced proliferation }\end{array}$ & Meniscus tissue & [17] \\
\hline Robocasting & $\begin{array}{l}\text { bovine small intestinal } \\
\text { submucosa (bSIS) } \\
\text { layers/HAp } \\
\text { microparticles/PCL }\end{array}$ & rat BMSCs seeding & $\begin{array}{l}\text { Enhanced cell proliferation and osteoblastic } \\
\text { differentiation within } 21 \text { days. Maximum } \\
\text { strength similar in cell-laden scaffolds and } \\
\text { cell-free scaffolds in wet conditions. } \\
\text { Different pore sizes with compressive } \\
\text { strengths comparable to cancellous bone. Sr } \\
\text { and Ag improved the mechanical strength } \\
\text { and cell proliferation and granted good } \\
\text { antimicrobial activity against Staphylococcus } \\
\text { aureus and Escherichia coli } \\
\text { Produced levofloxacin loaded scaffolds }\end{array}$ & Bone tissue engineering & {$[117]$} \\
\hline \multirow{4}{*}{ 3D bioprinting } & Biphasic $\mathrm{CaP}$ and chitosan & $\begin{array}{l}\text { hDNFs (human dermal } \\
\text { neonatal fibroblasts) }\end{array}$ & $\begin{array}{l}\text { without the sintering step. The antibiotic was } \\
\text { not degraded during the fabrication process } \\
\text { and its bactericidal efficacy was preserved }\end{array}$ & \multirow{4}{*}{ Bone tissue engineering } & \multirow[b]{2}{*}[133]{} \\
\hline & $\begin{array}{c}\text { PCL and bioactive borate } \\
\text { glass }\end{array}$ & hASCs-laden & $\begin{array}{l}\text { Controlled release of bioactive glass; more } \\
\text { than } 60 \% \text { viable hASCs on the scaffolds after } \\
1 \text { week of incubation. }\end{array}$ & & \\
\hline & Polycaprolactone (PCL) & Saos- 2 cells seeding & $\begin{array}{l}\text { The non-orthogonal structures showed } \\
\text { higher } E \text { moduli than the orthogonal one, } \\
\text { with a positive influence on the biological } \\
\text { performance of the cells; higher values for } \\
\text { the mineralization, activity of } \\
\text { osteogenic-related genes, and deposition of } \\
\text { the mineralized matrix }\end{array}$ & & {$[104]$} \\
\hline & Alginate/alginate-sulfate & MC3T3-E1 cells/BMP-2 & $\begin{array}{l}\text { Alginate/alginate sulfate bioinks allowed } \\
\text { good 3D cell printing. Improvement of the } \\
\text { release of BMP-2 was achieved using } \\
\text { alginate sulfate. Proliferation and } \\
\text { differentiation of the printed osteoblasts } \\
\text { were enhanced }\end{array}$ & & [90] \\
\hline
\end{tabular}


Table 1. Cont.

\begin{tabular}{|c|c|c|c|c|c|}
\hline Technology & Materials & Cells/Growth Factors & Outcomes & Application & Ref. \\
\hline & $\begin{array}{l}\text { GelMA and } \\
\text { methacrylated hyaluronic } \\
\text { acid (HA) modified with } \\
\text { HAp }\end{array}$ & hASCs & $\begin{array}{l}\text { Positive effects on bone matrix production } \\
\text { and remodelling }\end{array}$ & & {$[134]$} \\
\hline & $\begin{array}{l}\text { Collagen/dECM/silk } \\
\text { fibroin (SF) }\end{array}$ & MC3T3-E1 cells & $\begin{array}{l}\text { High compressive modulus mainly due to } \\
\text { the methanol-treated SF; high cellular } \\
\text { activities in in vitro tests using MC3T3-E1 } \\
\text { cells, induced by Collagen and dECM. }\end{array}$ & & {$[135]$} \\
\hline & $\alpha-\mathrm{TCP} /$ collagen & MC3T3-E1 cells & $\begin{array}{l}\text { The scaffold showed good mechanical } \\
\text { properties and cellular activities }\end{array}$ & & {$[128]$} \\
\hline & $\begin{array}{l}\text { collagen type I/agarose } \\
\text { with sodium alginate }\end{array}$ & Primary chondrocytes & $\begin{array}{l}\text { Addition of collagen or agarose had an } \\
\text { impact on gelling behavior and improving } \\
\text { mechanical strength. The collagen facilitated } \\
\text { cell adhesion, accelerated cell proliferation, } \\
\text { and enhanced the expression of } \\
\text { cartilage-specific genes, (Acan, Sox9, and } \\
\text { Col2a1) }\end{array}$ & & {$[126]$} \\
\hline & Fibrin and wollastonite & $\begin{array}{l}\text { Loaded with rabbit } \\
\text { BMSCs }\end{array}$ & $\begin{array}{l}\text { Possible extensive regeneration of both } \\
\text { cartilage and subchondral bone induced by } \\
\text { in vivo transplantation of the scaffolds }\end{array}$ & Osteochondral tissue & {$[136]$} \\
\hline & Collagen & MC3T3-E1 & $\begin{array}{l}\text { Cell-laden scaffold using tannic acid for } \\
\text { crosslinking process. TA crosslinking } \\
\text { increased mechanical properties and high } \\
\text { cell viability }\end{array}$ & n.d. & {$[127]$} \\
\hline & $\mathrm{CS} / \mathrm{PCL}$ & $\begin{array}{l}\mathrm{dECM} \text { coating/WJMSCs } \\
\text { seeding }\end{array}$ & $\begin{array}{l}\text { Improved osteogenic differentiation in vitro } \\
\text { and bone regenerative potential in vivo }\end{array}$ & Bone & {$[107]$} \\
\hline & $\mathrm{PCL} / \beta-\mathrm{TCP}$ & $\begin{array}{l}\text { dECM coating/MC3T3-E1 } \\
\text { seeding }\end{array}$ & $\begin{array}{l}\text { Improved osteogenic differentiation in vitro } \\
\text { and bone regenerative potential in vivo }\end{array}$ & Bone & {$[120]$} \\
\hline $\begin{array}{l}\text { Laser sintering } \\
\text { technique }\end{array}$ & PCL and HAp & - & $\begin{array}{l}\text { Subchondral bone regeneration and articular } \\
\text { cartilage formation in a rabbit model }\end{array}$ & Osteochondral tissue & {$[137]$} \\
\hline $\begin{array}{l}\text { Sol-gel method } \\
\text { combined with 3D } \\
\text { plotting }\end{array}$ & HAp/chitosan/silica & Mouse BMSCs seeding & $\begin{array}{l}\text { Compressive strength comparable to the } \\
\text { human trabecular bone }\end{array}$ & Bone regeneration & {$[138]$} \\
\hline
\end{tabular}


Table 1. Cont.

\begin{tabular}{|c|c|c|c|c|c|}
\hline Technology & Materials & Cells/Growth Factors & Outcomes & Application & Ref. \\
\hline \multirow{8}{*}{$\begin{array}{c}\text { BG obtained by sol-gel } \\
\text { method } \\
\text { Electrospinning } \\
\text { combined with } \\
\text { electro-spraying }\end{array}$} & Zein/bioactive glass (BG) & MG-63 cells seeding & $\begin{array}{c}\text { Ag-doped BG scaffolds showed antibacterial } \\
\text { properties. }\end{array}$ & & [139] \\
\hline & PCL/HAp & $\begin{array}{l}\text { Murine embryonic cell } \\
\text { seeding }\end{array}$ & $\begin{array}{l}\text { High capacity to guide the migration of } \\
\text { differentiated bone cells throughout the } \\
\text { cavities and the ridge of the scaffolds }\end{array}$ & & [140] \\
\hline & $\begin{array}{l}\text { PCL/gelatin and } \\
\text { multi-walled carbon } \\
\text { nanotubes (MWNTs) }\end{array}$ & $\begin{array}{l}\text { Adult rabbit chondrocytes } \\
\text { seeding }\end{array}$ & $\begin{array}{l}\text { Increased hydrophilicity and tensile strength, } \\
\text { and higher bioactivity and slower } \\
\text { degradation rate due to presence of MWNTs; }\end{array}$ & Cartilage tissue & [141] \\
\hline & $\begin{array}{l}\text { Graphene-incorporated } \\
\text { electrospun PCL/gelatin }\end{array}$ & PC12 cells & $\begin{array}{l}99 \% \text { antibacterial properties against } \\
\text { gram-positive and gram-negative bacteria. } \\
\text { Good cell attachment and proliferation }\end{array}$ & Nerve tissue engineering & [142] \\
\hline & PCL/collagen & $\begin{array}{l}\text { Human endometrial stem } \\
\text { cells seeding }\end{array}$ & $\begin{array}{l}\text { Higher wettability, attachment, and } \\
\text { proliferation rates of hEnSCs on the } \\
\text { PCL/collagen scaffold }\end{array}$ & Skin & [143] \\
\hline & $\begin{array}{l}\text { Polyhydroxybutyrate-co- } \\
\text { hydroxyvaletare (PHBV) } \\
\text { containing bredigite }\end{array}$ & - & $\begin{array}{l}\text { Bredigite nanoparticles increased the } \\
\text { mechanical properties, biodegradability, and } \\
\text { bioactivity of the scaffolds }\end{array}$ & Bone tissue & {$[144]$} \\
\hline & PLLA/ $\beta-\mathrm{TCP}$ & hMSCs seeding & $\begin{array}{c}\text { Enhanced water uptake ability, in vitro } \\
\text { bio-mineralization, and bioactivity promoted } \\
\text { by the incorporation of } \beta-\mathrm{TCP}\end{array}$ & Bone & {$[145]$} \\
\hline & PCL/Silk fibroin (SF) & Human fibroblast seeding & $\begin{array}{l}\text { Good tensile strength, elasticity, and } \\
\text { increased degradation rate, as well enhanced } \\
\text { cell proliferation, with the presence of SF }\end{array}$ & n.d. & [146] \\
\hline $\begin{array}{l}\text { Electrospinning } \\
\text { combined with 3D } \\
\text { bioprinting }\end{array}$ & PCL & $\begin{array}{l}\text { Laden with L929 mouse } \\
\text { fibroblasts }\end{array}$ & $\begin{array}{l}\text { Multi-layered structures-3D } \\
\text { scaffolds-with loosely packed nanofibers, } \\
\text { with better surface wettability (when } \\
\text { compared to the 2D scaffolds) }\end{array}$ & n.d. & [147] \\
\hline $\begin{array}{l}\text { Phase separation } \\
\text { process }\end{array}$ & $\begin{array}{c}\text { Cartilage } \\
\text { ECM-derived/PLGA- } \beta \text { - } \\
\text { TCP-collagen type I }\end{array}$ & BMSCs seeding & $\begin{array}{l}\text { Enhanced OC regeneration. Chondro and } \\
\text { osteogenic-induced BMSCs with } \\
\text { independent environments }\end{array}$ & Osteochondral tissue & [148] \\
\hline
\end{tabular}




\subsection{Hydrogel-Based Scaffolds}

Hydrogels are of particular interest for TE applications due to the distinctive properties of matrices formed through 3D networks. Particularly, hydrogel-based systems are highly hydrated structures that result from crosslinking reactions of polymers with hydrophilic natures that resemble the natural ECM of tissues [149]. Such properties ensure a suitable microenvironment for cells to grow, drug incorporation, and controlled release of biologically active agents. The elastic behavior and swelling capability of hydrogels makes them desired for injectable purposes and bioprinting applications, which is an emerging technology for the 3D fabrication of structures used for the construction of complex functional tissues and artificial organs, from nano- to macro-scales [150]. This innovative technology revolutionized the TERM field, not only because of the complexity of the biocompatible matrices, but also because of the opportunity to integrate cells and supporting components into the complex 3D functional architectures produced for transplantation. Compared with non-biological 3D printing, technical challenges related to the sensitivity of living cells to the shear stress during the bioprinting process can be found [151], which requires the integration of knowledge in the fields of engineering, biomaterials science, cell biology, and physics. Bioprinting techniques have already been proposed for the fabrication of 3D hydrogel-based structures, envisioning several tissue transplantations or substitutions, including skin [152], bone [153], vascular grafts [154], intervertebral disc (IVD) [102], meniscus, and cartilage [155]. More recently, the development of high-throughput in vitro platforms of healthy and diseased tissues of the human body came to address the TE field to a different level of precision medicine [156], and the 3D bioprinted hydrogels emerged as highly precise biomimetic matrices [157]. Apart from their use as aqueous-based systems for cell encapsulation [158], as injectable fillers [159], or in bioprinting technologies [160], different processing methodologies can be applied for structuring hydrogels into highly porous and composite matrices with superior mechanical properties, including solvent casting and particulate leaching, freeze-drying, phase separation, gas foaming, electroforming, and polymer blending [161-163]. These technologies have been proposed using different natural- and synthetic-based polymers, whose selection criteria depends on their chemistry, molecular weight, solubility, and hydrophilicity or hydrophobicity [164]. As aforementioned, the polymers of natural origin are in most cases an attractive option, mainly due to their similarities to the ECM and suitable biological performance [40]. However, their chemical versatility also brings molecular instability that can compromise hydrogel stability, degradability, and reproducibility [165]. On the other hand, the synthetic polymers are of controlled reproducibility and usually present superior mechanical properties and slow biological degradation, making them ideal for hard tissue applications or as indirect scaffolding strategies, serving as the structural basis for natural-origin hydrogels [166].

\subsubsection{Injectable Hydrogels}

Injectable hydrogels are highly attractive, especially as fillers of soft and hard tissues, promoting a good physical integration into the defect site and possibly avoiding open surgeries with hard recovery of the patients. The high water content of these hydrogels make them adjustable and easy to manipulate for the delivery of cells and growth factors. Usually, the hydrogel precursors are injected into the wound site in a solution-to-gelation transition (sol-gel) due to physical or chemical stimuli and crosslinking reactions [167]. The most common physical crosslinking methods for in situ hydrogelation reactions take place by the physical association between polymeric chains or nanoparticles, and include thermal gelation, ionic interactions, physical self-assembly, or photopolymerization [168-170]. The formation of chemically-induced hydrogels occurs via covalent bonds between polymeric chains promoted by agents such as glutaraldehyde or genipin and enzymes [171,172]. The physical methods of crosslinking, such as thermal gelation in physiological conditions, are easy to process and do not involve limitations of injection depth, as in the case of photopolymerization methods [173]. These crosslinking mechanisms can be even harder to control when applied in natural polymers, such as collagen or fibrin, which limits the final structural properties of the produced hydrogels. Kim et al. [174] reported chitosan/ $\beta$-glycerophosphate $(\mathrm{Ch} / \beta$-GP) thermo-sensitive hydrogels formed to deliver ellagic 
acid in cancer treatment. The heat-induced hydrogels were formed at body temperature but the final $\mathrm{pH}$ of the $\mathrm{Ch} / \beta$-GP solution affected the gelation temperature, time, and biocompatibility within the gels. The suitability of chitosan/ $\beta$-glycerophosphate to produce injectable thermosensitive and $\mathrm{pH}$-dependent hydrogels was also investigated in combination with starch, showing that its addition to the chitosan/ $\beta$-glycerophosphate solution did not alter the transition temperature and allowed the heating induced hydrogelation for applications in minimally invasive injectable systems [175]. Furthermore, thermal gelation is the main crosslinking method for obtaining dECM hydrogels. An example is the study of Alom et al. [176] that developed a decellularized and demineralized bovine bone ECM (bECM), and upon thermal induction, obtained a hydrogel suitable for bone regeneration. In fact, it was observed that Pluripotent myoblast C2C12 cell line and mouse primary calvarial cells (mPCs) cultured on top of bECM differentiated even in the absence of osteoinductive supplements.

Injectable hydrogels were proposed by Park et al. [177] as cartilaginous fillers composed of methacrylated glycol chitosan and hyaluronic acid photo-crosslinked with a riboflavin photoinitiator under visible light. The authors showed that a minimum radiation time was needed to produce stable hydrogels for cell encapsulation and chondrocyte viability. However, superior irradiation times that improved the hydrogels' mechanical properties for deep hydrogelation also compromised cell viability. Townsend et al. [178] pursued a photo-crosslinked method in order to develop a methacrylated decellularized cartilage hydrogel (MeSDCC) with HAp nanofibers (HAPnf), bioglass microparticles (BG), or rat BMSCs for calvarial bone regeneration. Despite the increase of the mechanical stiffness provided by the HAPnf and BG, the authors observed minimal bone regeneration in vivo for all conditions. The chemical methods used for producing hydrogels have been shown to offer controllable structural properties due to the covalent bonds between the polymeric chains, particularly due to the crosslinking density, which can be adjusted according to the polymer origin and tissue application [167]. Silk fibroin (SF) is a natural polymer proposed as an injectable filler of bone and cartilage tissues defects, due to its superior mechanical properties, biocompatibility, and in vivo degradation profile [179,180]. Different studies have shown that the sol-gel transition on SF hydrogelation can occur due to different physical and chemical methods, including mechanical agitation, ultra-sonication, thermal treatment, $\mathrm{pH}$ variations, organic solvents (methanol), ionic species $\left(\mathrm{Ca}^{2+}\right)$, or blending with other polymers containing hydroxyl groups (alginate, chitosan, or hyaluronic acid) [179,181-185] that induce the protein conformation transition from random coil to $\beta$-sheet ( $\beta$-sheet aggregates formation) [186] (Figure 6), or the crosslinking of fibroin molecules in the aqueous solution [187]. A different approach was recently proposed for SF hydrogel formation in random coil conformation, involving the enzymatic crosslinking of aqueous SF solutions promoted by the horseradish peroxidase (HRP)/hydrogen peroxide $\left(\mathrm{H}_{2} \mathrm{O}_{2}\right)$ complex $[188,189]$. In this system, the hydrogelation process was conducted in physiological conditions and the formed hydrogels underwent a spontaneous conformation transition to $\beta$-sheet over time. They showed timely and thermally responsive gelation properties, with tunable mechanical properties and viscoelastic properties of injectable matrices. Moreover, the possibility of encapsulating cells allow their viability and proliferation in the amorphous state, suggesting their use as artificial in vitro models for 3D microenvironment of tissue disorders and tumours. 

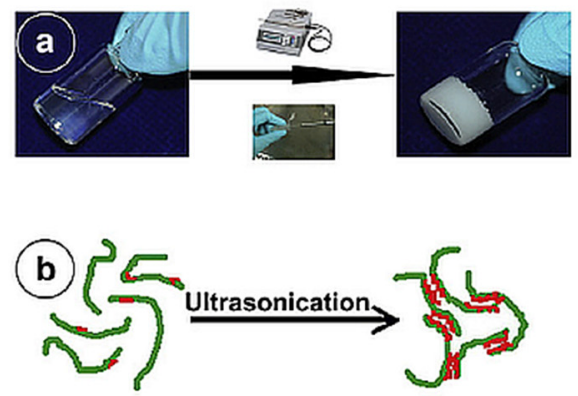

varn $\beta$-sheet structure

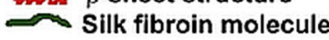
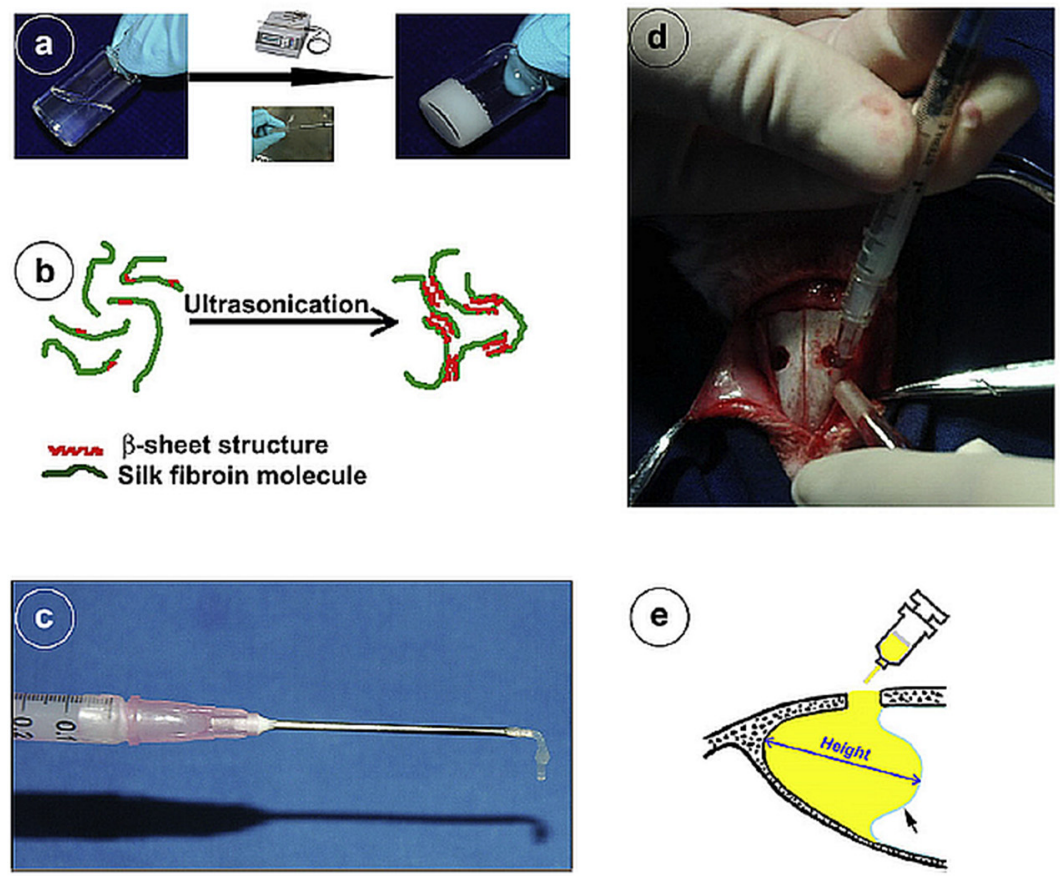

Figure 6. Sonication-induced silk fibroin hydrogel preparation. (a) Ultra-sonication procedure used for aqueous silk solution transformation into a solid silk hydrogel. (b) Schematic illustration of the mechanism of silk sol-gel transition due to physical crosslinking and $\beta$-sheet aggregate formation after ultra-sonication. (c) Injectable properties of the silk hydrogels. (d) Silk hydrogel being injected into rabbit maxillary sinus cavity. (e) Illustration of the elevated sinus in a sagittal plane being filled by the injected silk hydrogel. Reprinted from a previous study [179] with permission.

\subsubsection{D Printed Hydrogels}

3D printed hydrogels are produced through computer-assisted technologies, allowing fabrication of engineered tissues or matrices with superior control over their shape and reproducibility, with controlled physical and mechanical properties, and different layers and gradients, allowing generation of more complex tissue-like 3D architectures [190]. 3D printing technologies applied in cell-free approaches are well standardized and have been proposed using different hydrogel-based systems for conventional TERM strategies. For instance, Li et al. [191] proposed 3D printed hydrogels as OC defect fillers using alginate and hyaluronic acid as photo-polymerized bioinks. The OC tissue was restored by reverse engineering using high-resolution 3D scanning to obtain digital models of sample defects and corresponding parts after regeneration. The information was translated to the 3D printer, which extruded the combined hydrogel filaments in order to achieve the precise shape of the OC defects. Thus, the combination of 3D digital technologies with 3D printing was suggested as a possible solution to treat complex skeletal lesions in patient-specific approaches. Also, Costa et al. [102] have proposed a reverse engineering strategy to fabricate 3D models of annulus fibrosus (AF) as the outer region of IVD. In this strategy, semi-automatic morphological segmentation from magnetic resonance was used to image the dataset of human IVD, and then HRP-crosslinked SF/elastin hydrogels were used as bioinks for the printing of AF substitutes. In this study, HRP-crosslinked SF hydrogels are proposed for the first time as fast-setting bioinks for 3D printing of hydrogels in the amorphous state [192]. Their properties were fine-tuned for specific uses, presenting good resolution, reproducibility, and reliability (Figure 7). Moreover, the structures presented excellent mechanical properties and memory-shape features after processing, exhibiting potential applications in patient-specific strategies. A fourth (4D) generation of printed hydrogels was proposed by Gladman et al. [193] thatprinted composite hydrogels encoded with localized and anisotropic swelling properties promoted by the alignment of cellulose fibrils pre-established in the printing settings. It was shown that this nature-inspired 
shaper-morphing system presented biocompatible and flexible bioink properties, opening the design of new stimuli-responsive architectures for TE and biomedical applications.
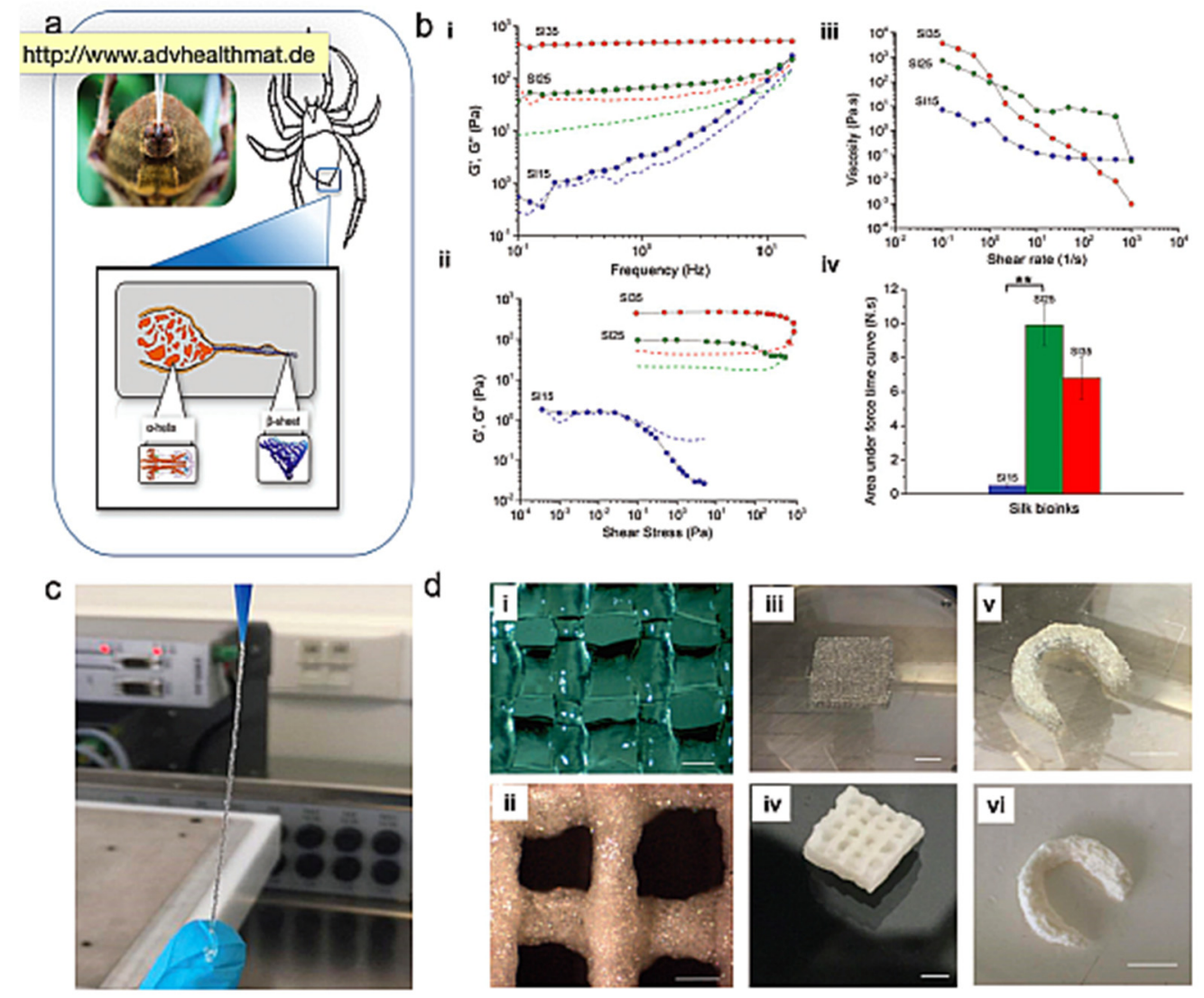

Figure 7. Silk fibroin bioinks and 3D printing of hydrogel-based scaffolds. (a) Schematic illustration of silk being extruded by a spider. (b) (i-iii) Rheological properties and (iv) adhesion measurements of the 3D printed hydrogels. (c) Extruded horseradish peroxidase (HRP)-crosslinked SF bioinks. (d) HRP-crosslinked SF scaffolds in the (i,iii,v) amorphous state and (ii,iv,vi) $\beta$-sheet crystalline conformation after freeze-drying and ethanol treatment. Reprinted from a previous study [192] with permission.

While the 3D printing technology is actually being applied for several TE and biomedical applications, it is a complex technology, since it involves not only computing and materials sciences, but also the interplay with other disciplines, such as cell-loading and developmental biological factors [31]. The interaction of multi-disciplinary technologies allows the development of more complex systems that better mimic the microarchitecture of tissues and organs. However, such complexity also creates a challenge in the design of functional 3D bioprinting. For example, the bioprinting parameters need to consider not only the heterogeneity of the polymeric materials (natural or synthetic) selected as bioinks, but also the influence of the cell-material dynamisms in the printing process. The shear-stress provoked during bioprinting not only affects the printing resolution but also cell viability and integrity [151]. Recent developments on creating spatial and temporal gradients within bioinks for regulating different cellular and molecular distributions along the hydrogels have also proved the increasing complexity in 3D bioprinting technologies [194]. For example, multiphase complex tissue structures of tendon-bone interface were obtained by creating multilayered gradients of encapsulated human mesenchymal stem cells (hMSCs) and growth factors (BMP-2 and TGF- $\beta 1$ ) embedded in anisotropic 3D hydrogels [195]. The controlled deposition of two or more cell populations in co-culture systems using 3D bioprinting has been attracting much attention for the production of engineered tissues with superior biological, biochemical, and physical properties. Duan et al. [196] 
implemented a 3D bioprinting system for the direct incorporation of dual cell types, sinus smooth muscle cells (SMC), and aortic valve leaflet interstitial cells (VIC) encapsulated in alginate and gelatin hydrogels for cardiovascular tissue. Reverse engineering was applied using micro-CT imaging of heart valves for the direct recreation of anatomically accurate aortic valve conduits through $3 \mathrm{D}$ bioprinting (Figure 8).
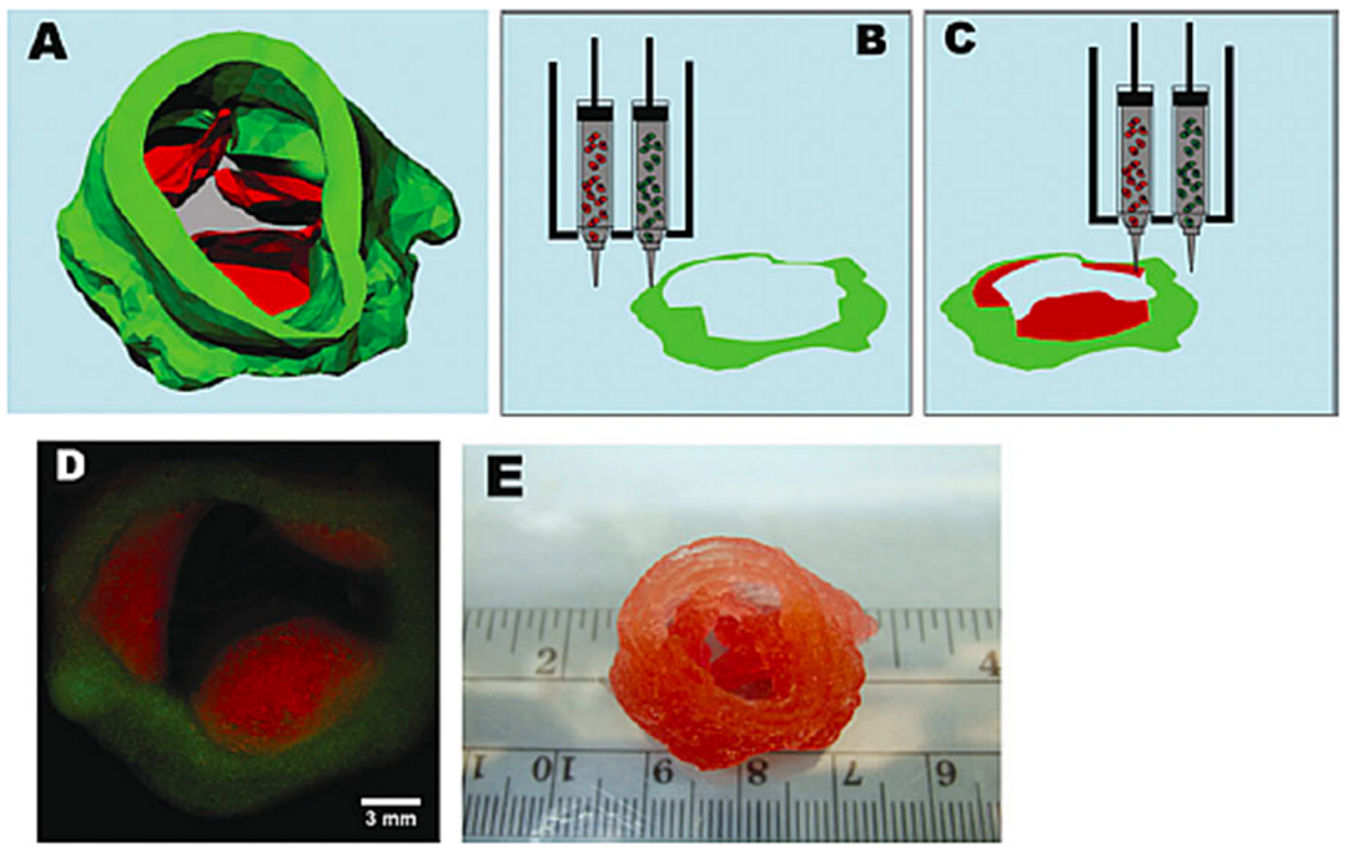

Figure 8. The 3D bioprinting of an aortic valve conduit. (A) The 3D reconstruction of an aortic valve model. The green color indicates valve root and the red color indicates valve leaflets. Schematic illustration of the 3D bioprinting process using alginate and gelatin as bioinks encapsulated with (B) sinus smooth muscle cells (SMCs) and (C) aortic valve leaflet interstitial cells (VIC) cells. (D) Fluorescent image of two 3D bioprinted layers representing an aortic valve conduit. (E) Macroscopic image of a 3D bioprinted aortic valve conduit. Reprinted from a previous study [196] with permission.

In a different study, Gaebel et al. [197] applied a Laser-Induced-Forward-Transfer (LIFT) cell printing technique to prepare cardiac patches for cardiac regeneration. A Polyester Urethane Urea (PEUU) was used as bioink for umbilical vein endothelial cells (HUVECs) and hMSCs bioprinting as pre-defined cardiac patches. The authors showed that the LIFT-derived cell seeding pattern affected cell growth of co-cultured HUVECs and hMSCs that migrated and accelerated vessel formation in the simulated cardiac patches. An increase in capillary density was also observed after cardiac patch transplantation in the myocardium of infarct-induced rats. All of these systems were optimized in order to recreate heterogeneous tissue and organs by precisely co-printing multiple cell-loaded materials with 3D architecture. Kolesky et al. [198] implemented a new custom-designed 3D bioprinter with four independent printheads able to sustain four different bioinks. Heterogeneous constructs consisting of HUVECs, human neonatal dermal fibroblasts (HNDFs), and 10T1/2 mouse fibroblasts were printed with a perfusable microvasculature network using gelatin methacrylate (GelMA) as bulk matrix and cell carrier. Using this highly scalable platform, the vascular network and multiple cell types were programmed to be precisely placed within the ECM simulator, refining the multi possibilities of 3D reconstruction of complex tissues and organs using bioprinting technologies.

In a different approach, the complex microstructure of the musculoskeletal system was mimicked using 3D integrated organ printing technology [199]. This system was used for processing and depositing four different components of an integrated muscle-tendon unit (MTU). Polyurethane (PU)-based hydrogels were used as bioinks and co-printed with C2C12 cells to develop the muscle region, and with NIH/3T3 cells for tendon development. The authors showed that the single construct 
was able to comprise the elastic properties of the muscle region and the stiffness of the tendon region only by using different cell types. The complex cell-matrix interactions were recaptured to form tissue constructs with region-specific biological and mechanical features.

\subsubsection{Porous Hydrogels}

As mentioned previously, the biocompatibility and structural similarities of hydrogels to the native ECM make them desirable for engineering different complex tissues. However, the big challenge remains to obtain precise control of certain hydrogel properties, such as porosity and mechanical properties. For certain tissues, especially those of the musculoskeletal system, a substantial amount of scaffold porosity is necessary to allow cell infiltration for ECM formation and secretion throughout the engineered tissues. Increased porosity and pore size can benefit the structure interconnectivity and the diffusion of nutrients and oxygen, especially in the absence of a pre-vascularized system, which is part of the microarchitectural composition of some tissues, such as cartilage, meniscus and IVD [166,200]. Another issue associated with hydrogels are their low mechanical properties and structural stability associated with the high-water-content that mimics the native ECM of tissues and allow cell encapsulation [201]. Thus, for some engineered tissues the possibility of structuring hydrogel-based matrices is a key role for regulating their microarchitecture and to improve many aspects of cell orientation, aggregation, and ECM function [202]. For example, in genipin crosslinked gelatin hydrogels with low porosity and pore size, the tendency of cells was to grow indiscriminately rather than produce and secrete ECM [203]. Consequently, the extent of ECM secretion was lower in these matrices as compared to that observed in gelatin hydrogels with larger pores, confirming that the porosity and pore interconnectivity greatly affect cell growth and penetration in the 3D structure of hydrogels. In a different study reported by our group [103], HRP-crosslinked SF hydrogels were structured using combined salt-leaching and freeze-drying methodologies for cartilage TE applications. The produced macro- and micro-porous SF hydrogels supported chondrogenic differentiation of human adipose-derived stem cells (hASCs) with a high degree of ECM formation and distribution within the porous matrices. The same matrices were further combined with macroand micro-porous HRP-crosslinked SF hydrogels incorporating $\beta$-TCP particles and used as bone-like layers in an osteochondral (OC) TE approach [162]. The bilayered structures presented high porosity and homogeneous pore distribution, with mechanical properties suitable for bone-cartilage tissue applications. The co-culture of human osteoblasts and human articular chondrocytes on the respective layers of the bilayered structures showed that both cell types adhered, proliferated, and produced their respective ECM in the cartilage- and bone-like compartments. As previously mentioned, the same HRP-crosslinked SF hydrogels have been proposed as aqueous hydrogel systems for 3D printing applications, and possibly injectable purposes $[189,192]$. However, some stability drawbacks were detected during the printing process of the amorphous SF, namely the hydrogel's mechanical resistance and stability in aqueous solution. Thus, through the salt-leaching processing or ethanol treatment applied to the HRP-crosslinked SF hydrogels, it was possible to induce a desired porosity and improve the hydrogel's structural stability due to the protein folding and $\beta$-sheet formation [102,161,162]. A new methodology to produce SF-based hollow tubular conduits (TCs) was described by Carvalho et al. [204], using the HRP-crosslinked SF hydrogels processed through three different methods (freeze-drying, drying at $50{ }^{\circ} \mathrm{C}$, permanent hydrated state), forming a crystalline $\beta$-sheet conformation after ethanol treatment. This approach allowed modulation of different characteristics of the final TCs, showing the hydrogel-based tubes with microstructures that ranged from nonporous to highly porous networks, which were selectively permeable to $4 \mathrm{kDa}$ molecules but not to human skin fibroblasts. The porous conduits also presented high tensile properties and good resistance to the applied loads. The fabrication of gradient structures brings a particular interest in the TE field, not only for the development of high-throughput 3D bioprinted materials, but also for the creation of hydrogel-based structures with controlled porosity and pore size [196]. Following this strategy, Canadas et al. [205,206] proposed in different studies the fabrication of innovative 3D architectures with linear or random porosity produced 
using gradient distributions induced by freeze-drying processing, varying temperatures, and guided crosslinking. ECM-like networks of OC tissue [205] and neuronal organization [207] were made of a photo-crosslinkable blend of methacrylated gellan gum (MAGG) and gelatin (GelMA) hydrogels, showing the ability to form different isotropic and anisotropic structures with tunable pore sizes and porosities according to the desired application (Figure 9). The possibility of forming gradient distributions using HAp microparticles in combination with growth factors was also demonstrated, as well as the development of a heterotypic-like OC tissue with cell orientation guided by a dual chamber bioreactor [205]. It was shown that by using a control over polymeric matrices composition, crosslinking directional properties, and freezing gradient dynamics, it was possible to develop 3D hydrogel-based structures with top-down tunable properties in terms of macro- and micro-porosity, and capable of guiding cell orientation and ECM formation. These works opened new opportunities of developing more complex tissue models for new drug testing and patient-specific therapies in regenerative medicine.

A

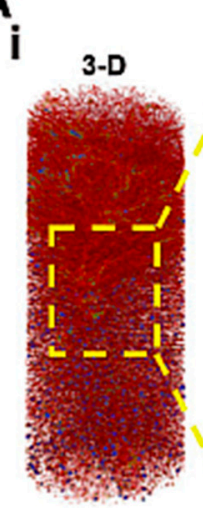

Cross-sections Ceramic phase

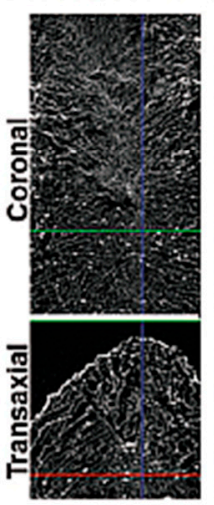

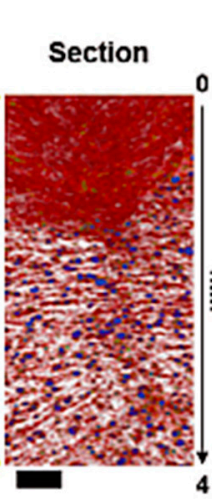

ii

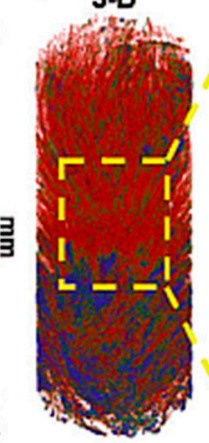

Cross-sections
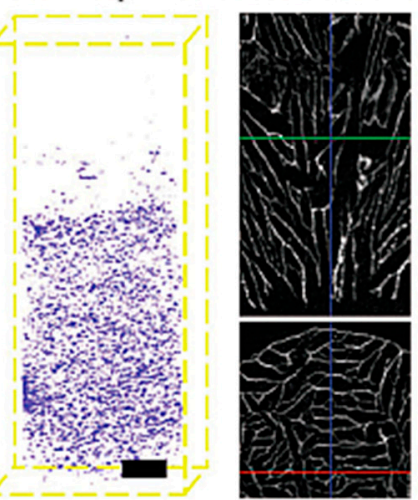

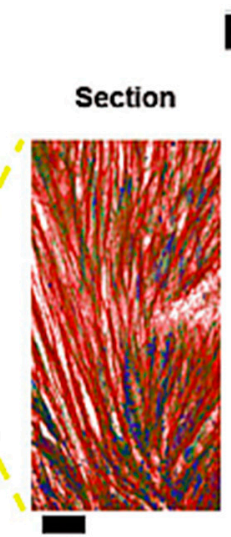

Ceramic phase

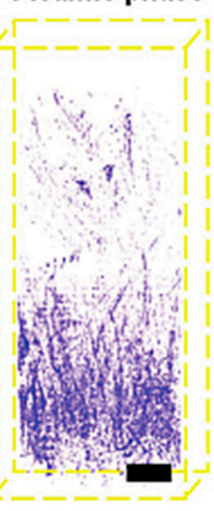

B

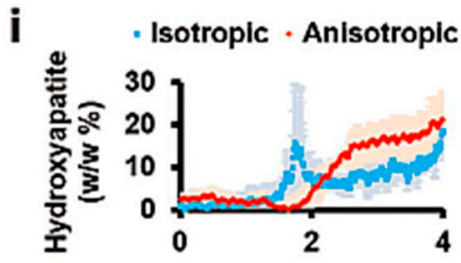

ii

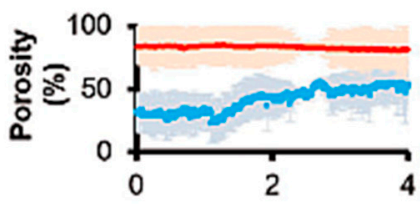

iij

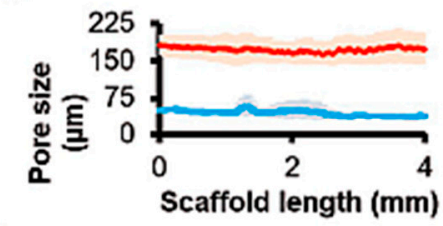

IV

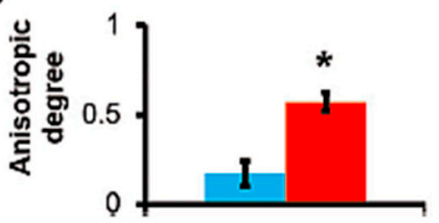

Figure 9. Structural characterization of gradient-induced 3D hydrogels. (A) The 3D reconstructions of: (i) random and (ii) linear porous architectures (isotropic and anisotropic). Red color represents methacrylated gelatin (GelMA)-methacrylated gellan gum (MAGG) blended polymers and blue color represents the hydroxyapatite (HAp) (Scale bar $=0.5 \mathrm{~mm}$ ). Coronal and transaxial sections of the bilayered phased structures are represented, showing the continuous interface created throughout the matrices. The ceramic phase distribution is shown in purple inside the structure's volume (Scale bar $=1 \mathrm{~mm}$ ). (B) Quantification profiles of (i) HAp distribution, (ii) porosity percentage, and (iii) mean pore size traced for isotropic and anisotropic structures with linear and random pore distribution. (iv) Anisotropic degree assessed for each porous architecture, showing higher values on the linear porous anisotropic structures. Data of anisotropic degree was represented as mean $\pm \mathrm{SD}$, ranging from 0 (isotropic) to 1 (anisotropic) $(P$-value $=0.05, \mathrm{~N}=3$ ). Reprinted from a previous study [205] with permission. 
The formation of bioactive polymer/inorganic hybrid hydrogels emerged as a new strategy for improving hydrogel mechanical stability, while porosity could also be increased [208]. Most of these strategies were developed for hard tissue applications, such as bone or OC complex, and include $\mathrm{CaPs}$ (HAp, $\alpha, \beta-\mathrm{TCP}$, or biphasic $\mathrm{CaP}$ ) or bioactive glass or glass-ceramics incorporation within the polymer-based hydrogel matrix [162,207-210]. For example, Ma et al. [211] proposed biomimetic hybrid hydrogels consisting of collagen, Hap, and alendronate for bone TE applications. First, the anti-osteoporosis drug alendronate was conjugated with bioactive HAp particles, further incorporated within the hydrogel matrix formed from collagen, and using genipin as the crosslinker. The authors have showed that the hybrid hydrogels formed in physiological conditions exhibited remarkable mechanical properties, higher gel content, and lower swelling rations as compared to the non-hybrid hydrogels prepared exclusively from collagen. In a different study, injectable composites were proposed for bone regeneration applications by combining alginate as a hydrogel matrix with crystalline $\mathrm{CaP}$ powders as dispersed minerals or used as sources of calcium for alginate crosslinking [212]. The viscoelastic properties of hydrogels were tunable according to CaP content, while still maintaining their injectability to fill bone defects. The biocompatibility and viscoelastic properties of alginate-based hydrogel matrices combined with the osteoconductivity of $\mathrm{CaP}$ particles were beneficial for bone regeneration and showed promising results as minimally invasive bone-filler materials. Jiang et al. [213], designed stratified OC grafts with multi-tissue regions, based on an agarose hydrogel matrix integrating composite microspheres of PLGA and 4555 bioactive glass (BG). The authors observed the ability of producing three distinct yet continuous regions of cartilage, calcified cartilage, and bone-like matrices by the incorporation of the PLGA-BG composite that promoted chondrocytes mineralization in the interface and the formation of a mineralized matrix in the osteoblast-cultured bone-like region. In addition, the PLGA-BG phase improved the mechanical properties of the multi-phased scaffolds, as compared to those prepared with PLGA alone and used as control.

In Table 2 some of the most recently reported studies are summarized using the aforementioned technologies and crosslinking methods to produce hydrogel-based matrices for TE purposes. 
Table 2. Technologies and crosslinking methods for producing innovative hydrogel-based matrices for TE applications.

\begin{tabular}{|c|c|c|c|c|c|}
\hline Technology & Materials & Crosslinking Method & Outcomes & Application & Ref. \\
\hline \multirow[t]{3}{*}{ Injectable hydrogels } & $\begin{array}{l}\text { Carboxymethyl chitosan and } \\
\text { alginate integrated with HAp } \\
\text { nanoparticles and calcium } \\
\text { carbonate microspheres } \\
\text { (CMs) }\end{array}$ & $\begin{array}{c}\text { Chemical crosslinking between } \\
\text { amino and aldehyde groups of } \\
\text { carboxymethyl chitosan } \\
\text { (CMCS) and oxidized alginate } \\
\text { (OAlg) }\end{array}$ & $\begin{array}{l}\text { Controlled gelation time, morphology, } \\
\text { mechanical properties, swelling ratio, } \\
\text { and in vitro degradation by varying } \\
\text { HAp and CMs contents; sustained drug } \\
\text { release and antibiotic activity against } \\
\text { bacteria }\end{array}$ & $\begin{array}{l}\text { Bone tissue engineering } \\
\text { and drug delivery }\end{array}$ & [214] \\
\hline & $\begin{array}{l}\text { Poly(ethylene } \\
\text { glycol)-N-hydroxysuccinimide } \\
\text { (PEG-NHS) }\end{array}$ & $\begin{array}{l}\text { Physical crosslinking using } \\
\text { gelatin functionalized with } \\
\text { norbornene groups (GelNB) } \\
\text { and crosslinked with } \\
\text { thiol-functionalized } \\
\text { poly(ethylene glycol) } \\
\text { (PEGdiSH) using a LAP } \\
\text { initiator }\end{array}$ & $\begin{array}{l}\text { Cell-laden ability inside the microgels } \\
\text { formed as 3D constructs; human BMSC } \\
\text { viability and function preservation } \\
\text { within the structures; upregulation of } \\
\text { chondrogenic activity and } \\
\text { glycosaminoglycans (GAGs) formation } \\
\text { encouraged by the assembled microgels }\end{array}$ & $\begin{array}{l}\text { Articular cartilage } \\
\text { regeneration }\end{array}$ & [215] \\
\hline & $\begin{array}{l}\text { Methacrylated decellularized } \\
\text { cartilage hydrogel (MeSDCC) } \\
\text { with HAp nanofibers } \\
\text { (HAPnf), or bioglass (BG) }\end{array}$ & Photo-crosslinking & $\begin{array}{l}\text { Increased mechanical stiffness and } \\
\text { minimal bone regeneration in vivo }\end{array}$ & Bone regeneration & [178] \\
\hline \multirow[t]{3}{*}{$3 \mathrm{D}$ printing } & $\begin{array}{l}\text { Alginate (AL), } \\
\text { Methylcellulose (MC), } \\
\text { Halloysite Nanotube (HNT), } \\
\text { and Polyvinylidene Fluoride } \\
\text { (PVDF) }\end{array}$ & $\begin{array}{l}\text { Chemical crosslinking using } \\
\text { calcium chloride }\left(\mathrm{CaCl}_{2}\right) \text { after } \\
\text { printing }\end{array}$ & $\begin{array}{l}\text { High water content and good miscibility } \\
\text { in the printed structures; chondrocyte } \\
\text { viability after } 4 \text { days of culture increased } \\
\text { by the presence of PVDF }\end{array}$ & Cartilage applications & [216] \\
\hline & $\begin{array}{l}\text { Sodium alginate (SA) and } \\
\text { gelatin }(\mathrm{Gel})\end{array}$ & $\begin{array}{l}\text { Chemical crosslinking induced } \\
\text { after printing by soaking in } \\
\mathrm{CaCl}_{2} \text { and glutaraldehyde }\end{array}$ & $\begin{array}{l}\text { The hydrogels showed high transparency } \\
\text { and excellent fluidic properties; } \\
\text { interconnected porous formation after 3D } \\
\text { architecting according to pre-established } \\
\text { operating parameters; 3D printed } \\
\text { architectures allowed chondrocyte } \\
\text { viability and proliferation with efficient } \\
\text { distribution within the porous structures }\end{array}$ & Cartilage repair & [217] \\
\hline & $\begin{array}{l}\text { Ultrapure alginate and } \\
\text { methylcellulose (Alg/MC) }\end{array}$ & $\begin{array}{l}\text { Chemical crosslinking by } \\
\text { Alg/MC blending }\end{array}$ & $\begin{array}{l}\text { Successful encapsulation of pancreatic } \\
\text { islets in hydrogels; good diffusion of } \\
\text { glucose and insulin within the structures, } \\
\text { with the embedded islets continuously } \\
\text { producing insulin and glucagon, while } \\
\text { still reacting to glucose stimulation }\end{array}$ & $\begin{array}{l}\text { Pancreatic islets } \\
\text { transplantation }\end{array}$ & [218] \\
\hline
\end{tabular}


Table 2. Cont

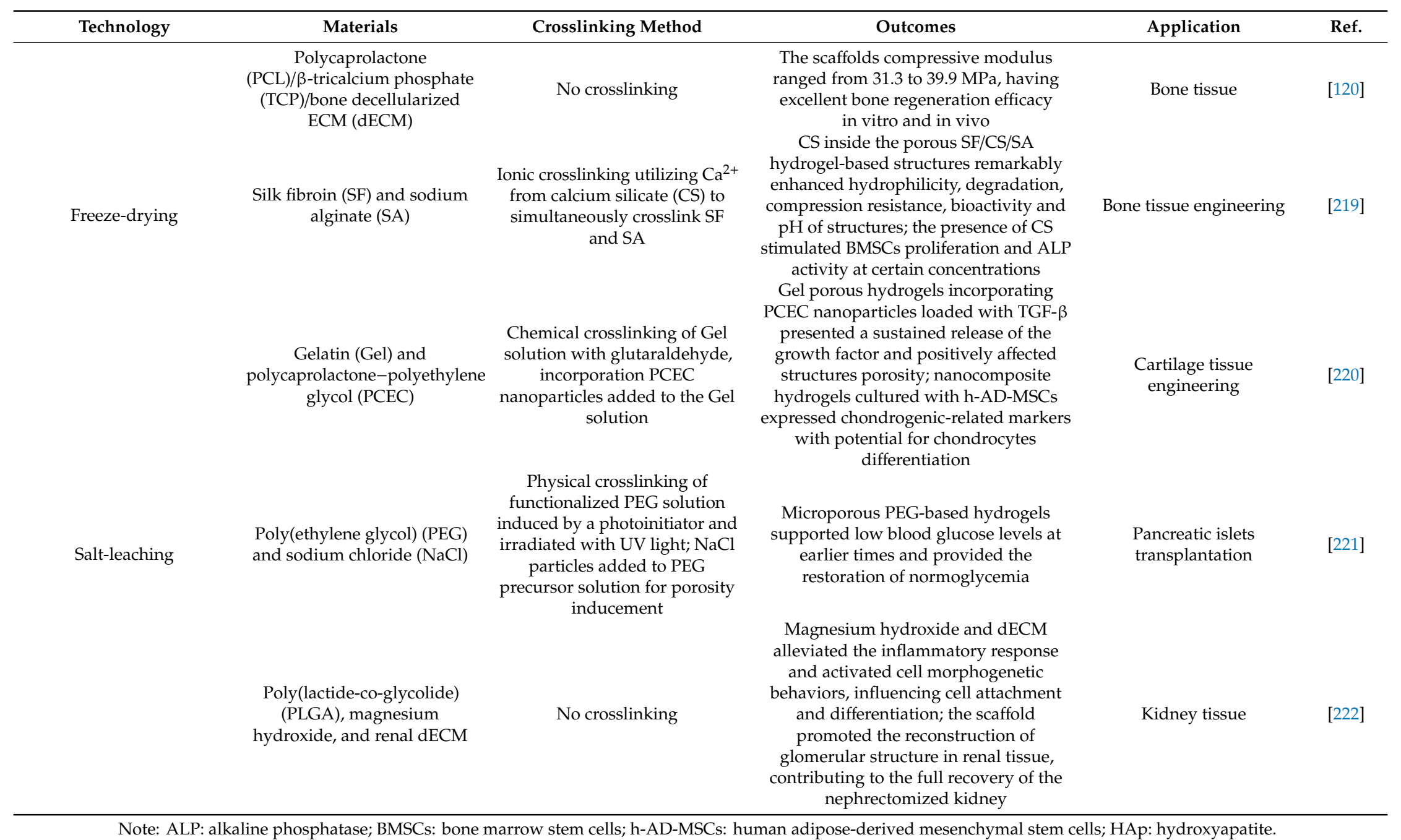

Note: ALP: alkaline phosphatase; BMSCs: bone marrow stem cells; h-AD-MSCs: human adipose-derived mesenchymal stem cells; HAp: hydroxyapatite. 


\section{Clinical Trials on Tissue Engineering/Regeneration}

Human clinical trials or interventional studies are conducted to evaluate biomedical or behavior interventions, including new treatments, after approval of the health ethics committee. This process involves multiple stages of R\&D studies before reaching the final stages of approval from the U.S. Food and Drug Administration (FDA). The FDA is a science-based agency in the US Public Health Service possessing legislative authority for premarket approval and post-market surveillance, and enforcement for a wide range of products in its regulatory preview. Research and development stages ensure the effectiveness and safety of new products and devices, which involve the production of medical grade scaffolds followed by animal testing under regulatory approved conditions. Over the last years, the research in TERM has resulted in few clinically approved therapeutics, but many more products are under development. Table 3 provides the completed and ongoing (with no reported results so far) preclinical research trials for TE applications using scaffolds and hydrogels in the last 5 years. 
Table 3. Overview of the complete and ongoing clinical trials, in the last 5 years, using scaffolds and hydrogel strategies for tissue engineering and regeneration. Information obtained from https://clinicaltrials.gov/.

\begin{tabular}{|c|c|c|c|c|c|c|}
\hline $\begin{array}{l}\text { ClinicalTrials.Gov } \\
\text { Identifier (NCT) }\end{array}$ & Date and Status & Study & Procedure & Patients Age & Follow-Up & Primary Outcomes \\
\hline NCT01301664 & 2013-2016 Completed & Cartilage Tissue Engineering & $\begin{array}{l}\text { Harvested human } \\
\text { cartilage tissues from } \\
\text { osteoarthritic patient } \\
\text { during total knee } \\
\text { arthroplasty surgery }\end{array}$ & $30-70$ years & n.d. & n.d. \\
\hline NCT01791062 & 2013-2016 Completed & $\begin{array}{l}\text { Safety and Efficacy Study of HYTOP }{ }^{\circledR} \text { in } \\
\text { the Treatment of Focal Chondral Defects }\end{array}$ & $\begin{array}{l}\text { Focal chondral defect in } \\
\text { femoro-tibial } \\
\text { compartment of the knee } \\
\text { joint }\end{array}$ & $18-50$ years & 12 weeks & $\begin{array}{l}\text { Adverse events with } \\
\text { causal relationship to the } \\
\text { investigational medical } \\
\text { device evaluated with } \\
\text { respect to type, incidence, } \\
\text { and intensity up to study } \\
\text { termination of each } \\
\text { subject }\end{array}$ \\
\hline NCT01879046 & 2013-2017 Completed & $\begin{array}{l}\text { Regenerative Medicine of Articular } \\
\text { Cartilage: Characterization and } \\
\text { Comparison of Chondrogenic Potential } \\
\text { and Immunomodulatory Adult } \\
\text { Mesenchymal Stem Cells }\end{array}$ & Total Knee arthroplasty & $\geq 18$ years & 3 years & $\begin{array}{l}\text { Increased expression of } \\
\text { chondrogenic markers }\end{array}$ \\
\hline NCT01813188 & $\begin{array}{l}\text { 2013-2017 Completed } \\
\text { (Phase 2) }\end{array}$ & $\begin{array}{l}\text { Use of bone marrow mononuclear cells } \\
\text { seeded onto a porous matrix of } \\
\text { tricalcium phosphate ceramic and } \\
\text { demineralized bone matrix, for the } \\
\text { consolidation of tibial bone defects } \\
\text { (pseudoarthrosis) }\end{array}$ & Autologous bone graft & $18-75$ years & 6 months & $\begin{array}{l}\text { Time needed to repair the } \\
\text { focus of necrosis } \\
\text { measured by pain } \\
\text { radiography }\end{array}$ \\
\hline NCT02033226 & $\begin{array}{l}\text { 2014-2015 Completed } \\
\text { (Phase 3) }\end{array}$ & $\begin{array}{c}\text { Evaluation of Clinical, } \\
\text { Anti-Inflammatory, and Anti-Infective } \\
\text { Properties of Amniotic Membranes Used } \\
\text { for Guided Tissue Regeneration in } \\
\text { Contained Defects }\end{array}$ & Chronic Periodontitis & $30-55$ years & 6 months & $\begin{array}{l}\text { The mean difference in } \\
\text { levels of hBD-2/IL-1 } \beta\end{array}$ \\
\hline
\end{tabular}


Table 3. Cont.

\begin{tabular}{|c|c|c|c|c|c|c|}
\hline $\begin{array}{l}\text { ClinicalTrials.Gov } \\
\text { Identifier (NCT) }\end{array}$ & Date and Status & Study & Procedure & Patients Age & Follow-Up & Primary Outcomes \\
\hline NCT01362413 & 2014-2015 Completed & $\begin{array}{l}\text { Validation of Laboratory Test for } \\
\text { Predicting Bone Tissue Regeneration } \\
\text { (Rebone-test) }\end{array}$ & $\begin{array}{l}\text { Nonunion of Fracture } \\
\text { (Pseudarthrosis) }\end{array}$ & $\geq 18$ years & 12 months & $\begin{array}{l}\text { Correlation between } \\
\text { laboratory results at the } \\
\text { surgery and clinical and } \\
\text { radiographic results at } 12 \\
\text { months, when patients } \\
\text { will be considered as } \\
\text { healed or not healed }\end{array}$ \\
\hline NCT02409628 & 2015-2017 Completed & $\begin{array}{c}\text { EktoTherix }{ }^{\mathrm{TM}} \text { Regenerative Tissue } \\
\text { Scaffold for Repair of Surgical Excision } \\
\text { Wounds }\end{array}$ & $\begin{array}{l}\text { Application of the } \\
\text { EktoTherix scaffold to a } \\
\text { fresh wound created by } \\
\text { the surgical removal of } \\
\text { non-melanoma skin } \\
\text { cancers }\end{array}$ & $\geq 18$ years & 3 months & $\begin{array}{l}\text { Incidence of device } \\
\text { related adverse events }\end{array}$ \\
\hline NCT02513368 & $\begin{array}{l}2015 \text { Completed } \\
\text { (Phase 2) }\end{array}$ & $\begin{array}{c}\text { Peri Implant Soft Tissue Healing in } \\
\text { Single Implant Restoration Using Two } \\
\text { Different Techniques }\end{array}$ & $\begin{array}{l}\text { Augmentation procedure } \\
\text { with Bio-Oss }{ }^{\circledR} \text { and } \\
\text { Bio-Gide }{ }^{\circledR}\end{array}$ & $18-75$ years & $\begin{array}{l}1 \text { year and } 1 \\
\text { month }\end{array}$ & $\begin{array}{c}\text { Change from baseline in } \\
\text { the clinical characteristics } \\
\text { of the peri implant } \\
\text { mucosa }\end{array}$ \\
\hline NCT00900718 & 2016 Completed & $\begin{array}{c}\text { Comparison of Straumann Bone } \\
\text { Ceramic and Bio-Oss With Guided } \\
\text { Tissue Regeneration for Alveolar Ridge } \\
\text { Preservation }\end{array}$ & $\begin{array}{l}\text { Bone augmentation, after } \\
\text { tooth extraction }\end{array}$ & $18-75$ years & 32 weeks & $\begin{array}{l}\text { The changes of bone level } \\
\text { between baseline and } \\
\text { 32-weeks post-extraction }\end{array}$ \\
\hline NCT02859025 & $\begin{array}{l}2016 \text { Completed } \\
\text { (Phase 1) }\end{array}$ & $\begin{array}{l}\text { Concomitant Use of Buccal Fat Pad } \\
\text { Derived Cells and Autogenous Bone in } \\
\text { Alveolar Cleft Osteoplasty }\end{array}$ & Cleft of Alveolar Ridge & $\begin{array}{l}\text { Child, adult } \\
\text { and older } \\
\text { adult }\end{array}$ & 6 months & Change in bone volume \\
\hline NCT03113747 & $\begin{array}{l}2017 \text { Completed } \\
\text { (Phase 1-2) }\end{array}$ & $\begin{array}{c}\text { Allogeneic Adipose derived stem cells } \\
\text { (ADSCs) and Platelet-Poor Plasma } \\
\text { Fibrin Hydrogel to Treat Patients with } \\
\text { Burn Wounds }\end{array}$ & $\begin{array}{c}\text { Application over } \\
\text { perforated autologous } \\
\text { skin graft following the } \\
\text { covering with } \\
\text { hypoadhesive bandage }\end{array}$ & $18-65$ years & 1 month & $\begin{array}{c}\text { The degree of healing of } \\
\text { skin flap after autologous } \\
\text { skin grafting }\end{array}$ \\
\hline NCT03076138 & 2017-2019 Completed & $\begin{array}{l}\text { Gene-activated Bone Substitute for } \\
\text { Maxillofacial Bone Regeneration }\end{array}$ & $\begin{array}{l}\text { Bone grafting with } \\
\text { gene-activated matrix } \\
\text { maxillofacial } \\
\text { regeneration }\end{array}$ & $18-60$ years & 6 months & $\begin{array}{l}\text { Bone tissue formation in } \\
\text { the field of gene-activated } \\
\text { bone substitute } \\
\text { implantation }\end{array}$ \\
\hline
\end{tabular}


Table 3. Cont.

\begin{tabular}{|c|c|c|c|c|c|c|}
\hline $\begin{array}{l}\text { ClinicalTrials.Gov } \\
\text { Identifier (NCT) }\end{array}$ & Date and Status & Study & Procedure & Patients Age & Follow-Up & Primary Outcomes \\
\hline NCT01605201 & $\begin{array}{l}2018 \text { Completed } \\
\text { (Phase 1) }\end{array}$ & $\begin{array}{c}\text { Tissue Engineered Nasal Cartilage for } \\
\text { Regeneration of Articular Cartilage } \\
\text { (Nose2Knee) }\end{array}$ & $\begin{array}{l}\text { Implantation of a graft in } \\
\text { a degenerative lesion of } \\
\text { articular cartilage of knee }\end{array}$ & $18-55$ years & 24 months & $\begin{array}{l}\text { Safety for the patient and } \\
\text { stability of the graft }\end{array}$ \\
\hline NCT02673905 & 2018 Recruiting & $\begin{array}{l}\text { Clinical Trial for the Regeneration of } \\
\text { Cartilage Lesions in the Knee } \\
\text { (NosetoKnee2) }\end{array}$ & $\begin{array}{l}\text { Articular cartilage lesions } \\
\text { in the knee }\end{array}$ & $18-65$ years & 24 months & $\begin{array}{l}\text { Comparison of the } \\
\text { efficacy of the two } \\
\text { investigational medicinal } \\
\text { products (IMPs) }\end{array}$ \\
\hline NCT02145130 & $\begin{array}{l}2018 \text { Recruiting } \\
\text { (Phase 1) }\end{array}$ & $\begin{array}{l}\text { Phase I Study for Autologous Dermal } \\
\text { Substitutes and Dermo-epidermal Skin } \\
\text { Substitutes for Treatment of Skin Defects }\end{array}$ & $\begin{array}{l}\text { Transplantation of an } \\
\text { autologous } \\
\text { tissue-engineered dermal } \\
\text { substitute }\end{array}$ & $1-70$ years & 21 days & $\begin{array}{l}\text { Assessment and } \\
\text { reporting of local } \\
\text { infection rate and graft } \\
\text { take }\end{array}$ \\
\hline NCT03613090 & $\begin{array}{l}2019 \text { Not yet } \\
\text { recruiting (Phase 2) }\end{array}$ & $\begin{array}{l}\text { Novel Collagen Scaffold versus } \\
\text { Conventional Scaffold in Regeneration } \\
\text { of Human Dental Pulp Tissue }\end{array}$ & $\begin{array}{l}\text { FDA-approved } \\
\text { collagen-hydroxyapatite } \\
\text { material called Syn-Oss } \\
\text { for regeneration of pulp } \\
\text { tissue }\end{array}$ & $\geq 12$ years & 15 months & $\begin{array}{c}\text { Observation of: } \\
\text { Radiodensity at apex at } \\
1 \mathrm{~mm} \text { from root vertex; } \\
\text { increase in dentin wall } \\
\text { thickness; increase in root } \\
\text { length, in mm, and } \\
\text { Periradicular status }\end{array}$ \\
\hline NCT02090140 & 2015-2020 Ongoing & $\begin{array}{l}\text { Microfracture Versus ADSCs for the } \\
\text { Treatment of Articular Cartilage Defects }\end{array}$ & $\begin{array}{l}\text { Microfracture followed } \\
\text { by the application of } \\
\text { ADSCs to the defect site }\end{array}$ & $18-50$ years & $\begin{array}{l}6,12,24 \\
\text { months }\end{array}$ & $\begin{array}{c}\text { Health Scores on the Knee } \\
\text { injury and Osteoarthritis } \\
\text { Outcome Score (KOOS) } \\
\text { Questionnaire }\end{array}$ \\
\hline
\end{tabular}


Table 3. Cont

\begin{tabular}{|c|c|c|c|c|c|c|}
\hline $\begin{array}{l}\text { ClinicalTrials.Gov } \\
\text { Identifier (NCT) }\end{array}$ & Date and Status & Study & Procedure & Patients Age & Follow-Up & Primary Outcomes \\
\hline NCT01765244 & $\begin{array}{l}\text { 2013-2020 Ongoing } \\
\text { (Phase I-II) }\end{array}$ & $\begin{array}{c}\text { Allogeneic Tissue Engineering } \\
\text { (Nanostructured Artificial Human } \\
\text { Cornea) in Patients with Corneal Trophic } \\
\text { Ulcers in Advanced Stages, Refractory to } \\
\text { Conventional (Ophthalmic) Treatment }\end{array}$ & $\begin{array}{l}\text { Implantation of an } \\
\text { anterior lamellar } \\
\text { nanostructured artificial } \\
\text { human cornea with } \\
\text { allogeneic cells from dead } \\
\text { donors embedded in a } \\
\text { fibrin-agarose scaffold }\end{array}$ & $\geq 18$ years & 24 months & $\begin{array}{l}\text { Adverse events (and } \\
\text { serious adverse events) } \\
\text { causally related to } \\
\text { experimental treatment; } \\
\text { implant status (integrity, } \\
\text { detachment, and } \\
\text { reabsorption); local, } \\
\text { regional, or systemic } \\
\text { infections related with the } \\
\text { implant; induced corneal } \\
\text { neovascularization }\end{array}$ \\
\hline NCT03698721 & 2018-2026 Ongoing & $\begin{array}{l}\text { Urothelium Tissue Engineering Using } \\
\text { Biopsies from Transurethral Resection of } \\
\text { Prostate }\end{array}$ & $\begin{array}{l}\text { Transurethral Resection } \\
\text { of Prostate }\end{array}$ & $\geq 18$ years & $\begin{array}{l}6,12,36 \\
\text { months }\end{array}$ & $\begin{array}{c}\text { Histological analysis of } \\
\text { biopsy }\end{array}$ \\
\hline NCT03103295 & $\begin{array}{l}2018 \text { Ongoing } \\
\text { (Phase 1-2) }\end{array}$ & $\begin{array}{l}\text { 3D Tissue Engineered Bone Equivalent } \\
\text { for Treatment of Traumatic Bone Defects }\end{array}$ & $\begin{array}{l}\text { Tissue-engineered } \\
\text { bone-like construct } \\
\text { transplantation }\end{array}$ & $18-60$ years & 12,36 months & $\begin{array}{l}\text { Radiographic and MRI } \\
\text { assessment in progression }\end{array}$ \\
\hline
\end{tabular}

Note: n.d.: not defined; ADSCs: adipose-derived stem cells. 
There are already some products with regulatory approval, such as: (i) bioceramics-based bone grafts substitutes, specifically CERAMENT ${ }^{\mathrm{TM}} \mathrm{G}$, Bonalive (Vivoxid Ltd., Turku, Finland), NovoMax ${ }^{\circledR}$ (BioAlpha Inc., Bandar Baru Bangi, Malaysia), ChronOs (DePuySynthes, Raynham, MA, USA), Straumann ${ }^{\circledR}$ BoneCeramic ${ }^{\mathrm{TM}}$ (Basel, Switzerland), and Geistlich Bio-Oss ${ }^{\circledR}$ (Wolhusen, Switzerland); (ii) scaffolding materials for cartilage repair and regeneration, namely Cartilage Repair Device (Kensey Nash Corp., Exton, PA, USA); and (iii) biomaterials for OC defect regeneration, such as MaioRegen ${ }^{\circledR}$ (Finceramic, Faenza, Italy), TruFit ${ }^{\circledR}$ (Smith and Nephew, Andover, MA, USA), and Cartilage Repair Device (Kensey Nash Corp., Exton, PA, USA). For small chondral and subchondral lesions treatment, there are also three off-the-shelf implants, namely ChondroMimetic ${ }^{\circledR}$ (TiGenix, Cambridge, UK), which is a collagen and CaP-bilayered scaffold, Agili-C ${ }^{\mathrm{TM}}$ (Rizzoli Orthopedic Institute, Bologna, Italy), an aragonite-based cell-free implant, and Chondrofix ${ }^{\circledR}$ (Zimmer Biomet, Warsaw) Allograft, which is a human decellularized hyaline cartilage and cancellous bone scaffold [220-224]. Marketed dECM scaffolds, harvested from several allogenic or xenogenic tissue sources, currently used in TERM are for the porcine small intestine (RestoreTM, DePuy Orthopedics; SurgiSIS ${ }^{\circledR}$, Cook Medical, Bloomington, IN, USA) and liver (MIRODERM ${ }^{\circledR}$; MIROMESH ${ }^{\circledR}$; Miromatrix Medical Inc., Eden Prairie, MN, USA), human dermis (AlloDermTM, LifeCell Corp., Branchburg, NJ, USA), porcine urinary bladder (MatriStemTM, ACellr, Inc., Lafayette, IN, USA), bovine pericardium (PhotoFix TEM, CryoLife Inc., Kennesaw, GA, USA), and porcine heart valve (PrimaTM Plus, Edwards Lifesciences LLC, Synergraft ${ }^{\circledR}$; CryoLife, Kennesaw, GA, USA) [225-228].

\section{Concluding Remarks and Future Perspectives}

There is a socioeconomic need to fully treat and replace damaged or non-functional tissues with pioneering approaches, designs, and technologies, converging on functional tissue reconstitution. TERM has appeared as a developing field based on materials engineering, biology, and medical knowledge struggling to produce alternative methods for the regeneration and repair of damaged tissues. Innovative strategies, such as the ones mentioned in this study, present out-of-the-box solutions for some of the current challenges in the TERM field, and may constitute foremost breakthroughs in the future. Such approaches will provide the production of bulk bioactive temporary implants with specific porosity and structure to contribute to the formation of new tissues for completing the medical tasks. The 3D scaffolds and hydrogel-based matrices are capable of meeting the challenges of personalized medicine, bringing effective treatments for an extensive assortment of pathologies. Hydrogel-based matrices have received a considerable interest for engineered tissue scaffolds owing to their structural similarities to natural ECM, as well as high water content, stiffness, and desirable structure for cellular proliferation. Furthermore, 3D bioprinted hydrogels arose as highly precise biomimetic matrices for the development of high-throughput in vitro models. Indeed, among the existing manufacturing technology, 3D bioprinting has been rapidly increasing with unlimited advantages of micro scale, high throughput, and cell deposition. Parallel to these advances, dECM has become popular in the TERM field owing to its ability to inherit the native ECM. In fact, besides the retention of the structure and biomolecules of the original tissues, $\mathrm{dECM}$ can be used for scaffolds, hydrogels, or even bioinks, alone or in combination with other materials, embracing different tissues. Nevertheless, there are still some issues, namely its low reproducibility among similar studies, which can be overcome through the standardization of the methods used for the decellularization process.

Considering the clinical trials status quo, although there are limited clinically approved tissue-engineered products, a rapid move toward more targeted therapies and customized treatments supported by 3D technologies has been noticed, particularly for cellular scaffold-based approaches.

Amongst the assortment of bioactive materials used for the production of 3D structures, composite materials appear to be the most promising ones. By combining polymer and ceramic biomaterials and simulating the natural tissues, better strength, adequate immune response, and biodegradability can be ensured. Although current research shows promising results, both from the mechanical and biological points of view, long-term studies are needed to ensure the implant-tissue interactions, resorption, and 
hierarchical structure, and finally to turn them into a clinically viable strategy. In this sense, some prospective improvements are under investigation to create enhanced TERM products, as demanded by regulatory approval bodies, before application in human patients. Improvement of cell-scaffold interaction with the use of cell-adhesive ligands, and changing cell morphology, alignment, and phenotype by functionalizing the surface of the scaffolds or even by mechanobiological stimulation of the cells open tremendous opportunities for regulation of TERM products.

Author Contributions: Conceptualization, S.P and V.P.R.; Methodology, S.P. and V.P.R.; Investigation, S.P., V.P.R., C.F.M. and F.R.M.; Writing - Original Draft Preparation, S.P., V.P.R., C.F.M. and F.R.M.; Writing-Review and Editing, S.P., T.H.S., R.L.R. and J.M.O. Supervision, T.H.S. and J.M.O.; Funding Administration, T.H.S., R.L.R. and J.M.O. All authors agree to be accountable for the work and to ensure that any questions relating to the accuracy and integrity of the paper are investigated and properly resolved.

Funding: This research was funded by Norte Portugal Regional Operational Programme (NORTE 2020), under the PORTUGAL 2020 Partnership Agreement, through the European Regional Development Fund (ERDF) (NORTE-01-0145-FEDER-000023) and by the Portuguese Foundation for Science and Technology ((M-ERA-NET/0022/2016), Transitional Rule DL 57/2016 (CTTI-57/18-I3BS(5)), and (IF/01285/2015)).

Conflicts of Interest: The authors declare no conflict of interest.

\section{References}

1. Berthiaume, F.; Maguire, T.J.; Yarmush, M.L. Tissue engineering and regenerative medicine: History, progress, and challenges. Annu. Rev. Chem. Biomol. Eng. 2011, 2, 403-430. [CrossRef] [PubMed]

2. Griffith, L.G.; Naughton, G. Tissue engineering-Current challenges and expanding opportunities. Science 2002, 295, 1009-1014. [CrossRef] [PubMed]

3. Khademhosseini, A.; Langer, R. Drug delivery and tissue engineering. Chem. Eng. Prog. 2006, 102, 38-42.

4. O'brien, F.J. Biomaterials \& scaffolds for tissue engineering. Mater. Today 2011, 14, 88-95.

5. Hubbell, J.A. Biomaterials in tissue engineering. Nat. Biotechnol. 1995, 13, 565. [CrossRef]

6. Place, E.S.; Evans, N.D.; Stevens, M.M. Complexity in biomaterials for tissue engineering. Nat. Mater. 2009, 8, 457. [CrossRef] [PubMed]

7. Ma, P.X. Biomimetic materials for tissue engineering. Adv. Drug Deliv. Rev. 2008, 60, 184-198. [CrossRef] [PubMed]

8. Furth, M.E.; Atala, A.; Van Dyke, M.E. Smart biomaterials design for tissue engineering and regenerative medicine. Biomaterials 2007, 28, 5068-5073. [CrossRef]

9. Xiao, X.; Wang, W.; Liu, D.; Zhang, H.; Gao, P.; Geng, L.; Yuan, Y.; Lu, J.; Wang, Z. The promotion of angiogenesis induced by three-dimensional porous beta-tricalcium phosphate scaffold with different interconnection sizes via activation of PI3K/Akt pathways. Sci. Rep. 2015, 5, 9409. [CrossRef]

10. Loh, Q.L.; Choong, C. Three-dimensional scaffolds for tissue engineering applications: Role of porosity and pore size. Tissue Eng. Part B Rev. 2013, 19, 485-502. [CrossRef]

11. Karageorgiou, V.; Kaplan, D. Porosity of 3D biomaterial scaffolds and osteogenesis. Biomaterials 2005, 26, 5474-5491. [CrossRef] [PubMed]

12. Wang, Y.; Rudym, D.D.; Walsh, A.; Abrahamsen, L.; Kim, H.-J.; Kim, H.S.; Kirker-Head, C.; Kaplan, D.L. In Vivo degradation of three-dimensional silk fibroin scaffolds. Biomaterials 2008, 29, 3415-3428. [CrossRef] [PubMed]

13. Ji, W.; Yang, F.; Seyednejad, H.; Chen, Z.; Hennink, W.E.; Anderson, J.M.; van den Beucken, J.J.; Jansen, J.A. Biocompatibility and degradation characteristics of PLGA-based electrospun nanofibrous scaffolds with nanoapatite incorporation. Biomaterials 2012, 33, 6604-6614. [CrossRef] [PubMed]

14. Dang, J.M.; Leong, K.W. Natural polymers for gene delivery and tissue engineering. Adv. Drug Deliv. Rev. 2006, 58, 487-499. [CrossRef] [PubMed]

15. Taylor, D.A.; Sampaio, L.C.; Ferdous, Z.; Gobin, A.S.; Taite, L.J. Decellularized matrices in regenerative medicine. Acta Biomater. 2018, 74, 74-89. [CrossRef] [PubMed]

16. Abedin, E.; Lari, R.; Shahri, N.M.; Fereidoni, M. Development of a demineralized and decellularized human epiphyseal bone scaffold for tissue engineering: A histological study. Tissue Cell 2018, 55, 46-52. [CrossRef] [PubMed] 
17. Zhang, Y.; Jiang, L.L.; Zheng, T.Z.; Sha, L.; Wang, J.Z.; Dong, H.C.; Song, K.D.; Liu, T.Q. Development of decellularized meniscus extracellular matrix and gelatin/chitosan scaffolds for meniscus tissue engineering. Bio-Med. Mater. Eng. 2019, 30, 125-132. [CrossRef]

18. Ghazanfari, S.; Alberti, K.A.; Xu, Q.B.; Khademhosseini, A. Evaluation of an elastic decellularized tendon-derived scaffold for the vascular tissue engineering application. J. Biomed. Mater. Res. Part A 2019, 107, 1225-1234. [CrossRef] [PubMed]

19. Parmaksiz, M.; Elçin, A.E.; Elçin, Y.M. Decellularized bovine small intestinal submucosa-PCL/hydroxyapatite-based multilayer composite scaffold for hard tissue repair. Mater. Sci. Eng. C 2019, 94, 788-797. [CrossRef]

20. Grant, R.; Hallett, J.; Forbes, S.; Hay, D.; Callanan, A. Blended electrospinning with human liver extracellular matrix for engineering new hepatic microenvironments. Sci. Rep. 2019, 9, 6293. [CrossRef]

21. Cho, A.-N.; Jin, Y.; Kim, S.; Kumar, S.; Shin, H.; Kang, H.-C.; Cho, S.-W. Aligned Brain Extracellular Matrix Promotes Differentiation and Myelination of Human-Induced Pluripotent Stem Cell-Derived Oligodendrocytes. ACS Appl. Mater. Interfaces 2019, 11, 15344-15353. [CrossRef] [PubMed]

22. Shin, H.; Jo, S.; Mikos, A.G. Biomimetic materials for tissue engineering. Biomaterials 2003, 24, $4353-4364$. [CrossRef]

23. Seal, B.; Otero, T.; Panitch, A. Polymeric biomaterials for tissue and organ regeneration. Mater. Sci. Eng. $R$ Rep. 2001, 34, 147-230. [CrossRef]

24. Dorozhkin, S.V. Calcium orthophosphates cements for biomedical application. J. Mater. Sci. Mater. Med. 2008, 43, 3028-3057. [CrossRef]

25. Place, E.S.; George, J.H.; Williams, C.K.; Stevens, M.M. Synthetic polymer scaffolds for tissue engineering. Chem. Soc. Rev. 2009, 38, 1139-1151. [CrossRef] [PubMed]

26. Sola, A.; Bertacchini, J.; D'Avella, D.; Anselmi, L.; Maraldi, T.; Marmiroli, S.; Messori, M. Development of solvent-casting particulate leaching (SCPL) polymer scaffolds as improved three-dimensional supports to mimic the bone marrow niche. Mater. Sci. Eng. C 2019, 96, 153-165. [CrossRef] [PubMed]

27. Brougham, C.M.; Levingstone, T.J.; Shen, N.; Cooney, G.M.; Jockenhoevel, S.; Flanagan, T.C.; O’brien, F.J. Freeze-Drying as a Novel Biofabrication Method for Achieving a Controlled Microarchitecture within Large, Complex Natural Biomaterial Scaffolds. Adv. Healthc. Mater. 2017, 6, 1700598. [CrossRef]

28. Song, P.; Zhou, C.; Fan, H.; Zhang, B.; Pei, X.; Fan, Y.; Jiang, Q.; Bao, R.; Yang, Q.; Dong, Z. Novel 3D porous biocomposite scaffolds fabricated by fused deposition modeling and gas foaming combined technology. Compos. Part B Eng. 2018, 152, 151-159. [CrossRef]

29. Kumar, T.S.; Chakrapani, V.Y. Electrospun 3D Scaffolds for Tissue Regeneration. In Cutting-Edge Enabling Technologies for Regenerative Medicine; Springer: Berlin, Germany, 2018; pp. $29-47$.

30. Gay, S.; Lefebvre, G.; Bonnin, M.; Nottelet, B.; Boury, F.; Gibaud, A.; Calvignac, B. PLA scaffolds production from Thermally Induced Phase Separation: Effect of process parameters and development of an environmentally improved route assisted by supercritical carbon dioxide. J. Supercrit. Fluids 2018, 136, 123-135. [CrossRef]

31. Lee, J.M.; Yeong, W.Y. Design and printing strategies in 3D bioprinting of cell-hydrogels: A review. Adv. Healthc. Mater. 2016, 5, 2856-2865. [CrossRef]

32. Xu, Y.; Wang, X. Application of 3D biomimetic models in drug delivery and regenerative medicine. Curr. Pharm. Des. 2015, 21, 1618-1626. [CrossRef] [PubMed]

33. Ozbolat, I.T.; Moncal, K.K.; Gudapati, H. Evaluation of bioprinter technologies. Addit. Manuf. 2017, 13, 179-200. [CrossRef]

34. Neves, L.S.; Rodrigues, M.T.; Reis, R.L.; Gomes, M.E. Current approaches and future perspectives on strategies for the development of personalized tissue engineering therapies. Expert Rev. Precis. Med. Drug Dev. 2016, 1, 93-108. [CrossRef]

35. Khademhosseini, A.; Langer, R. A decade of progress in tissue engineering. Nat. Protoc. 2016, 11, 1775. [CrossRef]

36. Kwakwa, K.A.; Vanderburgh, J.P.; Guelcher, S.A.; Sterling, J.A. Engineering 3D models of tumors and bone to understand tumor-induced bone disease and improve treatments. Curr. Osteoporos. Rep. 2017, 15, $247-254$. [CrossRef]

37. Shelke, N.B.; James, R.; Laurencin, C.T.; Kumbar, S.G. Polysaccharide biomaterials for drug delivery and regenerative engineering. Polym. Adv. Technol. 2014, 25, 448-460. [CrossRef] 
38. Sahana, T.G.; Rekha, P.D. Biopolymers: Applications in wound healing and skin tissue engineering. Mol. Biol. Rep. 2018, 45, 2857-2867. [CrossRef]

39. Bressan, E.; Favero, V.; Gardin, C.; Ferroni, L.; Iacobellis, L.; Favero, L.; Vindigni, V.; Berengo, M.; Sivolella, S.; Zavan, B. Biopolymers for Hard and Soft Engineered Tissues: Application in Odontoiatric and Plastic Surgery Field. Polymers 2011, 3, 509-526. [CrossRef]

40. Mano, J.; Silva, G.; Azevedo, H.; Malafaya, P.; Sousa, R.; Silva, S.; Reis, R. Natural origin biodegradable systems in tissue engineering and regenerative medicine: Present status and some moving trends. J. R. Soc. Interface 2007, 4, 999-1030. [CrossRef]

41. Nair, L.S.; Laurencin, C.T. Biodegradable polymers as biomaterials. Prog. Polym. Sci. 2007, 32, $762-798$. [CrossRef]

42. Malafaya, P.B.; Silva, G.A.; Reis, R.L. Natural-Origin polymers as carriers and scaffolds for biomolecules and cell delivery in tissue engineering applications. Adv. Drug Deliv. Rev. 2007, 59, 207-233. [CrossRef] [PubMed]

43. Pina, S.; Ferreira, J. Bioresorbable Plates and Screws for Clinical Applications: A Review. J. Healthc. Eng. 2012, 3, 243-260. [CrossRef]

44. Katti, D.S.; Lakshmi, S.; Langer, R.; Laurencin, C.T. Toxicity, biodegradation and elimination of polyanhydrides. Adv. Drug Deliv. Rev. 2002, 54, 933-961. [CrossRef]

45. Pereira, D.; Canadas, R.; Silva-Correia, J.; Marques, A.; Reis, R.; Oliveira, J. Gellan gum-based Hydrogel Bilayered Scaffolds for Osteochondral Tissue Engineering. Key Eng. Mater. 2014, 587, 255-260. [CrossRef]

46. Gunja, N.J.; Athanasiou, K.A. Biodegradable materials in arthroscopy. Sports Med. Arthrosc. 2006, 14, 112-119. [CrossRef] [PubMed]

47. Salinas, A.J.; Vallet-Regi, M. Bioactive ceramics: From bone grafts to tissue engineering. RSC Adv. 2013, 3, 11116-11131. [CrossRef]

48. Daculsi, G.; Laboux, O.; Malard, O.; Weiss, P. Current state of the art of biphasic calcium phosphate bioceramics. J. Mater. Sci.-Mater. Med. 2003, 14, 195-200. [CrossRef]

49. Bohner, M. Calcium orthophosphates in medicine: From ceramics to calcium phosphate cements. Inj.-Int. J. Care Inj. 2000, 31, 37-47. [CrossRef]

50. Silva, T.H.; Alves, A.; Ferreira, B.M.; Oliveira, J.M.; Reys, L.L.; Ferreira, R.J.F.; Sousa, R.A.; Silva, S.S.; Mano, J.F.; Reis, R.L. Materials of marine origin: A review on polymers and ceramics of biomedical interest. Int. Mater. Rev. 2012, 57, 276-306. [CrossRef]

51. Oliveira, J.M.; Grech, J.M.R.; Leonor, I.B.; Mano, J.F.; Reis, R.L. Calcium-phosphate derived from mineralized algae for bone tissue engineering applications. Mater. Lett. 2007, 61, 3495-3499. [CrossRef]

52. Correlo, V.M.; Oliveira, J.M.; Mano, J.F.; Neves, N.M.; Reis, R.L. CHAPTER 32-Natural Origin Materials for Bone Tissue Engineering-Properties, Processing, and Performance A2-Atala, Anthony. In Principles of Regenerative Medicine, 2nd ed.; Lanza, R., Thomson, J.A., Nerem, R., Eds.; Academic Press: San Diego, CA, USA, 2011; pp. 557-586. [CrossRef]

53. Oliveira, J.; Costa, S.; Leonor, I.; Malafaya, P.; Mano, J.; Reis, R. Novel hydroxyapatite/carboxymethylchitosan composite scaffolds prepared through an innovative "autocatalytic" electroless coprecipitation route. J. Biomed. Mater. Res. A 2009, 88, 470-480. [CrossRef] [PubMed]

54. Oliveira, J.M.; Kotobuki, N.; Tadokoro, M.; Hirose, M.; Mano, J.F.; Reis, R.L.; Ohgushi, H. Ex vivo culturing of stromal cells with dexamethasone-loaded carboxymethylchitosan/poly(amidoamine) dendrimer nanoparticles promotes ectopic bone formation. Bone 2010, 46, 1424-1435. [CrossRef] [PubMed]

55. Kannan, S.; Goetz-Neunhoeffer, F.; Neubauer, J.; Ferreira, J.M.F. Ionic substitutions in biphasic hydroxyapatite and beta-tricalcium phosphate mixtures: Structural analysis by rietveld refinement. J. Am. Ceram. Soc. 2008, 91, 1-12. [CrossRef]

56. Kannan, S.; Lemos, A.F.; Ferreira, J.M.F. Synthesis and mechanical performance of biological-like hydroxyapatites. Chem. Mater. 2006, 18, 2181-2186. [CrossRef]

57. Elliott, J.C. Structure and Chemistry of the Apatites and Other Calcium Orthophosphates; Elsevier: London, UK, 1994; Volume 18.

58. Fomin, A.; Barinov, S.; Ievlev, V.; Smirnov, V.; Mikhailov, B.; Belonogov, E.; Drozdova, N. Nanocrystalline hydroxyapatite ceramics produced by low-temperature sintering after high-pressure treatment. Dokl. Chem. 2008, 418, 22-25. [CrossRef] 
59. Pina, S.; Ferreira, J. Brushite-Forming Mg-, Zn-and Sr-Substituted Bone Cements for Clinical Applications. Materials 2010, 3, 519-535. [CrossRef]

60. Tomoaia, G.; Mocanu, A.; Vida-Simiti, I.; Jumate, N.; Bobos, L.D.; Soritau, O.; Tomoaia-Cotisel, M. Silicon effect on the composition and structure of nanocalcium phosphates: In Vitro biocompatibility to human osteoblasts. Mater. Sci. Eng. C Mater. Biol. Appl. 2014, 37, 37-47. [CrossRef]

61. Vallet-Regi, M.; Arcos, D. Silicon substituted hydroxyapatites. A method to upgrade calcium phosphate based implants. J. Mater. Chem. 2005, 15, 1509-1516. [CrossRef]

62. Kose, N.; Otuzbir, A.; Peksen, C.; Kiremitci, A.; Dogan, A. A silver ion-doped calcium phosphate-based ceramic nanopowder-coated prosthesis increased infection resistance. Clin. Orthop. Relat. Res. 2013, 471, 2532-2539. [CrossRef]

63. LeGeros, R.Z.; Kijkowska, R.; Bautista, C.; Retino, M.; LeGeros, J.P. Magnesium incorporation in apatites: Effect of CO3 and F. J. Dent. Res. 1996, 75, 60.

64. Pina, S.; Canadas, R.F.; Jiménez, G.; Perán, M.; Marchal, J.A.; Reis, R.L.; Oliveira, J.M. Biofunctional ionic-doped calcium phosphates-Silk fibroin composites for bone tissue engineering scaffolding. Cells Tissues Organs 2017, 204, 150-163. [CrossRef] [PubMed]

65. Mestres, G.; Le Van, C.; Ginebra, M.-P. Silicon-stabilized $\alpha$-tricalcium phosphate and its use in a calcium phosphate cement: Characterization and cell response. Acta Biomater. 2012, 8, 1169-1179. [CrossRef] [PubMed]

66. Pina, S.; Vieira, S.I.; Rego, P.; Torres, P.M.C.; Goetz-Neunhoeffer, F.; Neubauer, J.; da Cruz e Silva, O.A.B.; da Cruz e Silva, E.F.; Ferreira, J.M.F. Biological responses of brushite-forming Zn-and ZnSr-substituted $\beta$-TCP bone cements. Eur. Cells Mater. 2010, 20, 162-177, in press. [CrossRef]

67. Schwartsmann, C.R.; Boschin, L.C.; Gonçalves, R.Z.; Yépez, A.K.; Spinelli, L.d.F. Novas superfícies em artroplastia total do quadril. Rev. Bras. De Ortop. 2012, 47, 154-159. [CrossRef]

68. Shenoy, A.; Shenoy, N. Dental ceramics: An update. J. Conserv. Dent. 2010, 13, 195-203. [CrossRef]

69. Ritzberger, C.; Apel, E.; Höland, W.; Peschke, A.; Rheinberger, V.M. Properties and Clinical Application of Three Types of Dental Glass-Ceramics and Ceramics for CAD-CAM Technologies. Materials 2010, 3, 3700-3713. [CrossRef]

70. Available online: https://ceramics.org/ceramic-tech-today/biomaterials/glass-scaffolds-help-heal-bone (accessed on 15 April 2019).

71. Dorozhkin, S.V. Self-setting calcium orthophosphate formulations. J. Funct. Biomater. 2013, 4, $209-311$. [CrossRef]

72. Dorozhkin, S.V. Calcium Orthophosphates in Nature, Biology and Medicine. Materials 2009, 2, $399-498$. [CrossRef]

73. Wang, X.; Chang, J.; Wu, C. Bioactive inorganic/organic nanocomposites for wound healing. Appl. Mater. Today 2018, 11, 308-319. [CrossRef]

74. Tonsomboon, K.; Oyen, M. Composite electrospun gelatin fiber-alginate gel scaffolds for mechanically robust tissue engineered cornea. J. Mech. Behav. Biomed. Mater. 2013, 21, 185-194. [CrossRef]

75. Yeong, W.; Chua, C.; Leong, K.; Chandrasekaran, M. Rapid prototyping in tissue engineering: Challenges and potential. Trends Biotechnol. 2004, 22, 643-652. [CrossRef] [PubMed]

76. Gaharwar, A.K.; Schexnailder, P.J.; Schmidt, G. Nanocomposite Polymer Biomaterials for Tissue Repair of Bone and Cartilage: A Material Science Perspective. In Nanomaterials Handbook; Taylor \& Francis: Abingdon, UK, 2011; Volume 24.

77. Bonfield, W.; Grynpas, M.; Tully, A.; Bowman, J.; Abram, J. Hydroxyapatite reinforced polyethelene-A mechanically compatible implant material for bone replacement. Biomaterials 1981, 2, 185-186. [CrossRef]

78. Mintz, B.; Cooper, J.J. Hybrid hyaluronic acid hydrogel/poly (varepsilon-caprolactone) scaffold provides mechanically favorable platform for cartilage tissue engineering studies. J. Biomed. Mater. Res. A 2013, 102, 2918-2926. [CrossRef] [PubMed]

79. Yoshida, T.; Kikuchi, M.; Koyama, Y.; Takakuda, K. Osteogenic activity of MG63 cells on bone-like hydroxyapatite/collagen nanocomposite sponges. J. Mater. Sci. Mater. Med. 2010, 21, 1263-1272. [CrossRef] [PubMed]

80. Azami, M.; Samadikuchaksaraei, A.; Poursamar, S. Synthesis and characterization of a laminated hydroxyapatite/gelatin nanocomposite scaffold with controlled pore structure for bone tissue engineering. Int. J. Artif. Organs 2010, 33, 86-95. [CrossRef] [PubMed] 
81. Yan, L.; Salgado, A.; Oliveira, J.; Oliveira, A.; Reis, R. De novo bone formation on macro/microporous silk and silk/nano-sized calcium phosphate scaffolds. J. Bioact. Compat. Polym. 2013, 28, 439-452. [CrossRef]

82. Tanase, C.; Sartoris, A.; Popa, M.; Verestiuc, L.; Unger, R.; Kirkpatrick, C. In Vitro evaluation of biomimetic chitosan-calcium phosphate scaffolds with potential application in bone tissue engineering. Biomed. Mater. 2013, 8, 025002. [CrossRef]

83. Lee, G.; Park, J.; Shin, U.; Kim, H. Direct deposited porous scaffolds of calcium phosphate cement with alginate for drug delivery and bone tissue engineering. Acta Biomater. 2011, 7, 3178-3186. [CrossRef] [PubMed]

84. Heris, H.; Rahmat, M.; Mongeau, L. Characterization of a hierarchical network of hyaluronic acid/gelatin composite for use as a smart injectable biomaterial. Macromol. Biosci. 2012, 12, 202-210. [CrossRef] [PubMed]

85. Manda-Guiba, G.; Oliveira, M.; Mano, J.; Marques, A.; Oliveira, J.; Correlo, V.; Reis, R. Gellan gum-hydroxyapatite composite hydrogels for bone tissue engineering. J. Tissue Eng. Regen. Med. 2012, 6, 15.

86. Wang, Y.; Cui, W.; Chou, J.; Wen, S.; Sun, Y.; Zhang, H. Electrospun nanosilicates-based organic/inorganic nanofibers for potential bone tissue engineering. Colloids Surf. B Biointerfaces 2018, 172, 90-97. [CrossRef] [PubMed]

87. Thorrez, L.; Shansky, J.; Wang, L.; Fast, L.; VandenDriessche, T.; Chuah, M.; Mooney, D.; Vandenburgh, H. Growth, differentiation, transplantation and survival of human skeletal myofibers on biodegradable scaffolds. Biomaterials 2008, 29, 75-84. [CrossRef] [PubMed]

88. van de Witte, P.; Dijkstra, P.; van den Berg, J.; Feijen, J. Phase separation processes in polymer solutions in relation to membrane formation. J. Membr. Sci. 1996, 117, 1-31. [CrossRef]

89. Marrella, A.; Cavo, M.; Scaglione, S. Rapid Prototyping for the Engineering of Osteochondral Tissues. In Regenerative Strategies for the Treatment of Knee Joint Disabilities; Oliveira, J.M., Reis, R.L., Eds.; Springer International Publishing: Cham, Switzerland, 2017; pp. 163-185. [CrossRef]

90. Oliveira, A.L.; Sampaio, S.C.; Sousa, R.A.; Reis, R.L. Controlled mineralization of nature-inspired silk fibroin/hydroxyapatite hybrid bioactive scafolds for bone tissue engineering applications. In Proceedings of the 20th European Conference on Biomaterials, Nantes, France, 27 September-1 October 2006.

91. Yan, L.-P.; Silva-Correia, J.; Oliveira, M.B.; Vilela, C.; Pereira, H.; Sousa, R.A.; Mano, J.F.; Oliveira, A.L.; Oliveira, J.M.; Reis, R.L. Bilayered silk/silk-nanoCaP scaffolds for osteochondral tissue engineering: In vitro and in vivo assessment of biological performance. Acta Biomater. 2015, 12, 227-241. [CrossRef] [PubMed]

92. Yan, L.-P.; Oliveira, J.M.; Oliveira, A.L.; Caridade, S.G.; Mano, J.F.; Reis, R.L. Macro/microporous silk fibroin scaffolds with potential for articular cartilage and meniscus tissue engineering applications. Acta Biomater. 2012, 8, 289-301. [CrossRef] [PubMed]

93. Abdelaal, O.; Darwish, S. Fabrication of tissue engineering scaffolds using rapid prototyping techniques. World Acad. Sci. Eng. Technol. 2011, 59, 577-585.

94. Chae, T.; Yang, H.; Leung, V.; Ko, F.; Troczynski, T. Novel biomimetic hydroxyapatite/alginate nanocomposite fibrous scaffolds for bone tissue regeneration. J. Mater. Sci. Mater. Med. 2013, 24, 1885-1894. [CrossRef] [PubMed]

95. Cui, L.; Zhang, N.; Cui, W.; Zhang, P.; Chen, X. A novel nano/micro-fibrous scaffold by melt-spinning method for bone tissue engineering. J. Bionic Eng. 2015, 12, 117-128. [CrossRef]

96. Cardea, S.; Scognamiglio, M.; Reverchon, E. Supercritical fluid assisted process for the generation of cellulose acetate loaded structures, potentially useful for tissue engineering applications. Mater. Sci. Eng. C 2016, 59, 480-487. [CrossRef] [PubMed]

97. Oliveira, J.M.; Rodrigues, M.T.; Silva, S.S.; Malafaya, P.B.; Gomes, M.E.; Viegas, C.A.; Dias, I.R.; Azevedo, J.T.; Mano, J.F.; Reis, R.L. Novel hydroxyapatite/chitosan bilayered scaffold for osteochondral tissue-engineering applications: Scaffold design and its performance when seeded with goat bone marrow stromal cells. Biomaterials 2006, 27, 6123-6137. [CrossRef] [PubMed]

98. Costa, J.B.; Silva-Correia, J.; Reis, R.L.; Oliveira, J.M. Current advances in solid free-form techniques for osteochondral tissue engineering. Bio-Des. Manuf. 2018, 1, 171-181. [CrossRef]

99. Grigalevičiūtè, G.; Baltriukienè, D.; Balčiūnas, E.; Jonušauskas, L.; Malinauskas, M. Fabrication of flexible microporous 3D scaffolds via stereolithography and optimization of their biocompatibility. In Proceedings of the SPIE OPTO, San Francisco, CA, USA, 27 January-1 February 2018; p. 6. 
100. Tohamy, K.M.; Soliman, I.E.; Mabrouk, M.; ElShebiney, S.; Beherei, H.H.; Aboelnasr, M.A.; Das, D.B. Novel polysaccharide hybrid scaffold loaded with hydroxyapatite: Fabrication, bioactivity, and In Vivo study. Mater. Sci. Eng. C 2018, 93,1-11. [CrossRef] [PubMed]

101. Oliveira, J.; Silva, S.; Malafaya, P.; Rodrigues, M.; Kotobuki, N.; Hirose, M.; Reis, R. Macroporous hydroxyapatite scaffolds for bone tissue engineering applications: Physicochemical characterization and assessment of rat bone marrow stromal cell viability. J. Biomed. Mater. Res. A 2009, 91, 175-186. [CrossRef] [PubMed]

102. Costa, J.B.; Silva-Correia, J.; Ribeiro, V.P.; da Silva Morais, A.; Oliveira, J.M.; Reis, R.L. Engineering patient-specific bioprinted constructs for treatment of degenerated intervertebral disc. Mater. Today Commun. 2018. [CrossRef]

103. Ribeiro, V.P.; da Silva Morais, A.; Maia, F.R.; Canadas, R.F.; Costa, J.B.; Oliveira, A.L.; Oliveira, J.M.; Reis, R.L. Combinatory approach for developing silk fibroin scaffolds for cartilage regeneration. Acta Biomater. 2018, 72, 167-181. [CrossRef] [PubMed]

104. Fonseca, D.R.; Sobreiro-Almeida, R.; Sol, P.C.; Neves, N.M. Development of non-orthogonal 3D-printed scaffolds to enhance their osteogenic performance. Biomater. Sci. 2018, 6, 1569-1579. [CrossRef]

105. Diogo, G.S.; López-Senra, E.L.; Pirraco, R.P.; Canadas, R.F.; Fernandes, E.M.; Serra, J.; Pérez-Martín, R.I.; Sotelo, C.G.; Marques, A.P.; González, P.; et al. Marine Collagen/Apatite Composite Scaffolds Envisaging Hard Tissue Applications. Mar. Drugs 2018, 16, 269. [CrossRef]

106. Agarwal, T.; Maiti, T.K.; Ghosh, S.K. Decellularized caprine liver-derived biomimetic and pro-angiogenic scaffolds for liver tissue engineering. Mater. Sci. Eng. C-Mater. Biol. Appl. 2019, 98, 939-948. [CrossRef]

107. Wu, Y.H.A.; Chiu, Y.C.; Lin, Y.H.; Ho, C.C.; Shie, M.Y.; Chen, Y.W. 3D-Printed Bioactive Calcium Silicate/Poly-epsilon-Caprolactone Bioscaffolds Modified with Biomimetic Extracellular Matrices for Bone Regeneration. Int. J. Mol. Sci. 2019, 20, 19. [CrossRef]

108. Wilson, K.; Terlouw, A.; Roberts, K.; Wolchok, J.C. The characterization of decellularized human skeletal muscle as a blueprint for mimetic scaffolds. J. Mater. Sci. Mater. Med. 2016, 27, 125. [CrossRef]

109. Bose, S.; Ke, D.; Sahasrabudhe, H.; Bandyopadhyay, A. Additive manufacturing of biomaterials. Prog. Mater. Sci. 2018, 93, 45-111. [CrossRef]

110. Wang, X.; Jiang, M.; Zhou, Z.; Gou, J.; Hui, D. 3D printing of polymer matrix composites: A review and prospective. Compos. Part B: Eng. 2017, 110, 442-458. [CrossRef]

111. Smay, J.E.; Cesarano, J.; Lewis, J.A. Colloidal Inks for Directed Assembly of 3-D Periodic Structures. Langmuir 2002, 18, 5429-5437. [CrossRef]

112. Bandyopadhyay, A.; Bose, S. Additive Manufacturing. Available online: http://www.crcnetbase.com/isbn/ 9781482223590 (accessed on 31 April 2019).

113. Stuecker, J.N.; Cesarano, J.; Hirschfeld, D.A. Control of the viscous behavior of highly concentrated mullite suspensions for robocasting. J. Mater. Process. Technol. 2003, 142, 318-325. [CrossRef]

114. Miranda, P.; Saiz, E.; Gryn, K.; Tomsia, A.P. Sintering and robocasting of $\beta$-tricalcium phosphate scaffolds for orthopaedic applications. Acta Biomater. 2006, 2, 457-466. [CrossRef] [PubMed]

115. Heo, S.-J.; Kim, S.-E.; Wei, J.; Hyun, Y.-T.; Yun, H.-S.; Kim, D.-H.; Shin, J.W.; Shin, J.-W. Fabrication and characterization of novel nano-and micro-HA/PCL composite scaffolds using a modified rapid prototyping process. J. Biomed. Mater. Res. Part A 2009, 89, 108-116. [CrossRef] [PubMed]

116. Martínez-Vázquez, F.J.; Perera, F.H.; Miranda, P.; Pajares, A.; Guiberteau, F. Improving the compressive strength of bioceramic robocast scaffolds by polymer infiltration. Acta Biomater. 2010, 6, 4361-4368. [CrossRef]

117. Marques, C.F.; Perera, F.H.; Marote, A.; Ferreira, S.; Vieira, S.I.; Olhero, S.; Miranda, P.; Ferreira, J.M.F. Biphasic calcium phosphate scaffolds fabricated by direct write assembly: Mechanical, anti-microbial and osteoblastic properties. J. Eur. Ceram. Soc. 2017, 37, 359-368. [CrossRef]

118. Goodman, S.B.; Yao, Z.; Keeney, M.; Yang, F. The future of biologic coatings for orthopaedic implants. Biomaterials 2013, 34, 3174-3183. [CrossRef]

119. Marques, C.F.; Olhero, S.M.; Torres, P.M.C.; Abrantes, J.C.C.; Fateixa, S.; Nogueira, H.I.S.; Ribeiro, I.A.C.; Bettencourt, A.; Sousa, A.; Granja, P.L.; et al. Novel sintering-free scaffolds obtained by additive manufacturing for concurrent bone regeneration and drug delivery: Proof of concept. Mater. Sci. Eng. C 2019, 94, 426-436. [CrossRef]

120. Kim, J.Y.; Ahn, G.; Kim, C.; Lee, J.S.; Lee, I.G.; An, S.H.; Yun, W.S.; Kim, S.Y.; Shim, J.H. Synergistic Effects of Beta Tri-Calcium Phosphate and Porcine-Derived Decellularized Bone Extracellular Matrix in 3D-Printed Polycaprolactone Scaffold on Bone Regeneration. Macromol. Biosci. 2018, 18, 10. [CrossRef] [PubMed] 
121. Jang, J.; Park, J.Y.; Gao, G.; Cho, D.-W. Biomaterials-based 3D cell printing for next-generation therapeutics and diagnostics. Biomaterials 2018, 156, 88-106. [CrossRef] [PubMed]

122. Park, J.; Lee, S.J.; Lee, H.; Park, S.A.; Lee, J.Y. Three dimensional cell printing with sulfated alginate for improved bone morphogenetic protein-2 delivery and osteogenesis in bone tissue engineering. Carbohydr. Polym. 2018, 196, 217-224. [CrossRef] [PubMed]

123. Giuseppe, M.D.; Law, N.; Webb, B.; Macrae, R.A.; Liew, L.J.; Sercombe, T.B.; Dilley, R.J.; Doyle, B.J. Mechanical behaviour of alginate-gelatin hydrogels for 3D bioprinting. J. Mech. Behav. Biomed. Mater. 2018, 79, 150-157. [CrossRef] [PubMed]

124. Lee, K.Y.; Mooney, D.J. Alginate: Properties and biomedical applications. Prog. Polym. Sci. 2012, 37, $106-126$. [CrossRef]

125. Chung, J.H.Y.; Naficy, S.; Yue, Z.; Kapsa, R.; Quigley, A.; Moulton, S.E.; Wallace, G.G. Bio-ink properties and printability for extrusion printing living cells. Biomater. Sci. 2013, 1, 763-773. [CrossRef]

126. Yang, X.; Lu, Z.; Wu, H.; Li, W.; Zheng, L.; Zhao, J. Collagen-alginate as bioink for three-dimensional (3D) cell printing based cartilage tissue engineering. Mater. Sci. Eng. C 2018, 83, 195-201. [CrossRef]

127. Lee, J.; Yeo, M.; Kim, W.; Koo, Y.; Kim, G.H. Development of a tannic acid cross-linking process for obtaining 3D porous cell-laden collagen structure. Int. J. Biol. Macromol. 2018, 110, 497-503. [CrossRef]

128. Kim, W.J.; Yun, H.-S.; Kim, G.H. An innovative cell-laden $\alpha$-TCP/collagen scaffold fabricated using a two-step printing process for potential application in regenerating hard tissues. Sci. Rep. 2017, 7, 3181. [CrossRef]

129. Türk, S.; Altınsoy, I.; Çelebi Efe, G.; Ipek, M.; Özacar, M.; Bindal, C. 3D porous collagen/functionalized multiwalled carbon nanotube/chitosan/hydroxyapatite composite scaffolds for bone tissue engineering. Mater. Sci. Eng. C 2018, 92, 757-768. [CrossRef]

130. Jiang, L.B.; Su, D.H.; Liu, P.; Ma, Y.Q.; Shao, Z.Z.; Dong, J. Shape-memory collagen scaffold for enhanced cartilage regeneration: Native collagen versus denatured collagen. Osteoarthr. Cartil. 2018, 26, 1389-1399. [CrossRef] [PubMed]

131. Del Bakhshayesh, A.R.; Mostafavi, E.; Alizadeh, E.; Asadi, N.; Akbarzadeh, A.; Davaran, S. Fabrication of Three-Dimensional Scaffolds Based on Nano-biomimetic Collagen Hybrid Constructs for Skin Tissue Engineering. ACS Omega 2018, 3, 8605-8611. [CrossRef]

132. Kolahreez, D.; Morshed, M. Fabrication of porous three-dimensional fibroin structures through a freezing process. J. Appl. Polym. Sci. 2018, 135, 13. [CrossRef]

133. Murphy, C.; Kolan, K.; Li, W.; Semon, J.; Day, D.; Leu, M. 3D bioprinting of stem cells and polymer/bioactive glass composite scaffolds for bone tissue engineering. Int. J. Bioprint. 2017, 3, 11. [CrossRef]

134. Wenz, A.; Borchers, K.; Tovar, G.E.M.; Kluger, P.J. Bone matrix production in hydroxyapatite-modified hydrogels suitable for bone bioprinting. Biofabrication 2017, 9, 044103. [CrossRef] [PubMed]

135. Lee, H.; Yang, G.H.; Kim, M.; Lee, J.; Huh, J.; Kim, G. Fabrication of micro/nanoporous collagen/dECM/silk-fibroin biocomposite scaffolds using a low temperature 3D printing process for bone tissue regeneration. Mater. Sci. Eng. C 2018, 84, 140-147. [CrossRef] [PubMed]

136. Shen, T.; Dai, Y.K.; Li, X.G.; Xu, S.Z.; Gou, Z.R.; Gao, C.Y. Regeneration of the Osteochondral Defect by a Wollastonite and Macroporous Fibrin Biphasic Scaffold. ACS Biomater. Sci. Eng. 2018, 4, 1942-1953. [CrossRef]

137. Du, Y.; Liu, H.; Yang, Q.; Wang, S.; Wang, J.; Ma, J.; Noh, I.; Mikos, A.G.; Zhang, S. Selective laser sintering scaffold with hierarchical architecture and gradient composition for osteochondral repair in rabbits. Biomaterials 2017, 137, 37-48. [CrossRef]

138. Dong, Y.F.; Liang, J.N.; Cui, Y.H.; Xu, S.; Zhao, N.R. Fabrication of novel bioactive hydroxyapatite-chitosan-silica hybrid scaffolds: Combined the sol-gel method with 3D plotting technique. Carbohydr. Polym. 2018, 197, 183-193. [CrossRef]

139. El-Rashidy, A.A.; Waly, G.; Gad, A.; Roether, J.A.; Hum, J.; Yang, Y.Y.; Detsch, R.; Hashem, A.A.; Sami, I.; Goldmann, W.H.; et al. Antibacterial activity and biocompatibility of zein scaffolds containing silver-doped bioactive glass. Biomed. Mater. 2018, 13, 13. [CrossRef] 
140. Garcia, A.G.; Hebraud, A.; Duval, J.L.; Wittmer, C.R.; Gaut, L.; Duprez, D.; Egles, C.; Bedoui, F.; Schlatter, G.; Legallais, C. Poly (epsilon-caprolactone)/Hydroxyapatite 3D Honeycomb Scaffolds for a Cellular Microenvironment Adapted to Maxillofacial Bone Reconstruction. ACS Biomater. Sci. Eng. 2018, 4, 3317-3326. [CrossRef]

141. Zadehnajar, P.; Akbari, B.; Karbasi, S.; Mirmusavi, M.H. Preparation and characterization of poly $\varepsilon$-caprolactone-gelatin/multi-walled carbon nanotubes electrospun scaffolds for cartilage tissue engineering applications. Int. J. Polym. Mater. Polym. Biomater. 2019, 1-12. [CrossRef]

142. Heidari, M.; Bahrami, S.H.; Ranjbar-Mohammadi, M.; Milan, P.B. Smart electrospun nanofibers containing PCL/gelatin/graphene oxide for application in nerve tissue engineering. Mater. Sci. Eng. C 2019, 103, 109768. [CrossRef]

143. Sharif, S.; Ai, J.; Azami, M.; Verdi, J.; Atlasi, M.A.; Shirian, S.; Samadikuchaksaraei, A. Collagen-coated nano-electrospun PCL seeded with human endometrial stem cells for skin tissue engineering applications. J. Biomed. Mater. Res. Part B 2018, 106, 1578-1586. [CrossRef] [PubMed]

144. Kouhi, M.; Fathi, M.; Jayarama Reddy, V.; Ramakrishna, S. Bredigite Reinforced Electrospun Nanofibers for Bone Tissue Engineering. Mater. Today Proc. 2019, 7, 449-454. [CrossRef]

145. Lee, S.; Joshi, M.K.; Tiwari, A.P.; Maharjan, B.; Kim, K.S.; Yun, Y.H.; Park, C.H.; Kim, C.S. Lactic acid assisted fabrication of bioactive three-dimensional PLLA/beta-TCP fibrous scaffold for biomedical application. Chem. Eng. J. 2018, 347, 771-781. [CrossRef]

146. Nazeer, M.A.; Yilgor, E.; Yilgor, I. Electrospun polycaprolactone/silk fibroin nanofibrous bioactive scaffolds for tissue engineering applications. Polymer 2019, 168, 86-94. [CrossRef]

147. Gao, Q.; Gu, H.; Zhao, P.; Zhang, C.; Cao, M.; Fu, J.; He, Y. Fabrication of electrospun nanofibrous scaffolds with 3D controllable geometric shapes. Mater. Des. 2018, 157, 159-169. [CrossRef]

148. Da, H.; Jia, S.J.; Meng, G.L.; Cheng, J.H.; Zhou, W.; Xiong, Z.; Mu, Y.J.; Liu, J. The impact of compact layer in biphasic scaffold on osteochondral tissue engineering. PLoS ONE 2013, 8, e54838. [CrossRef]

149. Lee, J.-H.; Kim, H.-W. Emerging properties of hydrogels in tissue engineering. J. Tissue Eng. 2018, 9, 2041731418768285. [CrossRef]

150. Mandrycky, C.; Wang, Z.; Kim, K.; Kim, D.-H. 3D bioprinting for engineering complex tissues. Biotechnol. Adv. 2016, 34, 422-434. [CrossRef] [PubMed]

151. Blaeser, A.; Duarte Campos, D.F.; Puster, U.; Richtering, W.; Stevens, M.M.; Fischer, H. Controlling shear stress in 3D bioprinting is a key factor to balance printing resolution and stem cell integrity. Adv. Healthc. Mater. 2016, 5, 326-333. [CrossRef] [PubMed]

152. Velasco, D.; Quílez, C.; Garcia, M.; del Cañizo, J.F.; Jorcano, J.L. 3D human skin bioprinting: A view from the bio side. J. 3D Print. Med. 2018, 2, 141-162. [CrossRef]

153. Ashammakhi, N.; Hasan, A.; Kaarela, O.; Byambaa, B.; Sheikhi, A.; Gaharwar, A.K.; Khademhosseini, A. Advancing Frontiers in Bone Bioprinting. Adv. Healthc. Mater. 2019. [CrossRef] [PubMed]

154. Miri, A.K.; Khalilpour, A.; Cecen, B.; Maharjan, S.; Shin, S.R.; Khademhosseini, A. Multiscale bioprinting of vascularized models. Biomaterials 2019, 198, 204-216. [CrossRef] [PubMed]

155. Roseti, L.; Cavallo, C.; Desando, G.; Parisi, V.; Petretta, M.; Bartolotti, I.; Grigolo, B. Three-dimensional bioprinting of cartilage by the use of stem cells: A strategy to improve regeneration. Materials 2018, 11, 1749. [CrossRef] [PubMed]

156. Devarasetty, M.; Mazzocchi, A.R.; Skardal, A. Applications of bioengineered 3D tissue and tumor organoids in drug development and precision medicine: Current and future. BioDrugs 2018, 32, 53-68. [CrossRef]

157. Garcia, J.; Yang, Z.; Mongrain, R.; Leask, R.L.; Lachapelle, K. 3D printing materials and their use in medical education: A review of current technology and trends for the future. BMJ Simul. Technol. Enhanc. Learn. 2018, 4, 27-40. [CrossRef] [PubMed]

158. Bryant, S.J.; Vernerey, F.J. Programmable hydrogels for cell encapsulation and neo-tissue growth to enable personalized tissue engineering. Adv. Healthc. Mater. 2018, 7, 1700605. [CrossRef] [PubMed]

159. Varma, D.M.; Gold, G.T.; Taub, P.J.; Nicoll, S.B. Injectable carboxymethylcellulose hydrogels for soft tissue filler applications. Acta Biomater. 2014, 10, 4996-5004. [CrossRef]

160. Wang, S.; Lee, J.M.; Yeong, W.Y. Smart hydrogels for 3D bioprinting. Int. J. Bioprinting 2015, 2, 1. [CrossRef]

161. Ribeiro, V.; Pina, S.; Costa, J.B.; Cengiz, I.F.; García-Fernández, L.; Fernández-Gutiérrez, M.d.M.; Paiva, O.C.; Oliveira, A.L.; San Roman, J.; Oliveira, J.M. Enzymatically crosslinked silk fibroin-based hierarchical scaffolds for osteochondral regeneration. ACS Appl. Mater. Interfaces 2019, 11, 3781-3799. [CrossRef] [PubMed] 
162. De France, K.J.; Xu, F.; Hoare, T. Structured Macroporous Hydrogels: Progress, Challenges, and Opportunities. Adv. Healthc. Mater. 2018, 7, 1700927. [CrossRef] [PubMed]

163. Dhandayuthapani, B.; Yoshida, Y.; Maekawa, T.; Kumar, D.S. Polymeric scaffolds in tissue engineering application: A review. Int. J. Polym. Sci. 2011, 2011. [CrossRef]

164. Drury, J.L.; Mooney, D.J. Hydrogels for tissue engineering: Scaffold design variables and applications. Biomaterials 2003, 24, 4337-4351. [CrossRef]

165. Guarino, V.; Gloria, A.; Raucci, M.G.; Ambrosio, L. Hydrogel-based platforms for the regeneration of osteochondral tissue and intervertebral disc. Polymers 2012, 4, 1590-1612. [CrossRef]

166. Tan, H.; Marra, K.G. Injectable, biodegradable hydrogels for tissue engineering applications. Materials 2010, 3, 1746-1767. [CrossRef]

167. Nguyen, K.T.; West, J.L. Photopolymerizable hydrogels for tissue engineering applications. Biomaterials 2002, 23, 4307-4314. [CrossRef]

168. Burke, S.A.; Ritter-Jones, M.; Lee, B.P.; Messersmith, P.B. Thermal gelation and tissue adhesion of biomimetic hydrogels. Biomed. Mater. 2007, 2, 203. [CrossRef]

169. Silva, S.S.; Popa, E.G.; Gomes, M.E.; Oliveira, M.B.; Nayak, S.; Subia, B.; Mano, J.F.; Kundu, S.C.; Reis, R.L. Silk hydrogels from non-mulberry and mulberry silkworm cocoons processed with ionic liquids. Acta Biomater. 2013, 9, 8972-8982. [CrossRef]

170. Silva, S.S.; Motta, A.; Rodrigues, M.T.; Pinheiro, A.F.; Gomes, M.E.; Mano, J.F.; Reis, R.L.; Migliaresi, C. Novel genipin-cross-linked chitosan/silk fibroin sponges for cartilage engineering strategies. Biomacromolecules 2008, 9, 2764-2774. [CrossRef] [PubMed]

171. Mansur, H.S.; Sadahira, C.M.; Souza, A.N.; Mansur, A.A. FTIR spectroscopy characterization of poly (vinyl alcohol) hydrogel with different hydrolysis degree and chemically crosslinked with glutaraldehyde. Mater. Sci. Eng. C 2008, 28, 539-548. [CrossRef]

172. Klouda, L. Thermoresponsive hydrogels in biomedical applications: A seven-year update. Eur. J. Pharm. Biopharm. 2015, 97, 338-349. [CrossRef] [PubMed]

173. Kim, S.; Nishimoto, S.K.; Bumgardner, J.D.; Haggard, W.O.; Gaber, M.W.; Yang, Y. A chitosan/ $\beta$-glycerophosphate thermo-sensitive gel for the delivery of ellagic acid for the treatment of brain cancer. Biomaterials 2010, 31, 4157-4166. [CrossRef] [PubMed]

174. Sá-Lima, H.; Caridade, S.G.; Mano, J.F.; Reis, R.L. Stimuli-responsive chitosan-starch injectable hydrogels combined with encapsulated adipose-derived stromal cells for articular cartilage regeneration. Soft Matter 2010, 6, 5184-5195. [CrossRef]

175. Alom, N.; Peto, H.; Kirkham, G.R.; Shakesheff, K.M.; White, L.J. Bone extracellular matrix hydrogel enhances osteogenic differentiation of $\mathrm{C} 2 \mathrm{C} 12$ myoblasts and mouse primary calvarial cells. J. Biomed. Mater. Res. Part B 2018, 106, 900-908. [CrossRef]

176. Park, H.; Choi, B.; Hu, J.; Lee, M. Injectable chitosan hyaluronic acid hydrogels for cartilage tissue engineering. Acta Biomater. 2013, 9, 4779-4786. [CrossRef]

177. Townsend, J.M.; Zabel, T.A.; Feng, Y.; Wang, J.; Andrews, B.T.; Nudo, R.J.; Berkland, C.J.; Detamore, M.S. Effects of tissue processing on bioactivity of cartilage matrix-based hydrogels encapsulating osteoconductive particles. Biomed. Mater. 2018, 13, 11. [CrossRef]

178. Zhang, W.; Wang, X.; Wang, S.; Zhao, J.; Xu, L.; Zhu, C.; Zeng, D.; Chen, J.; Zhang, Z.; Kaplan, D.L. The use of injectable sonication-induced silk hydrogel for VEGF165 and BMP-2 delivery for elevation of the maxillary sinus floor. Biomaterials 2011, 32, 9415-9424. [CrossRef]

179. Cipriani, F.; Krüger, M.; de Torre, I.G.; Sierra, L.Q.; Rodrigo, M.A.; Kock, L.; Rodriguez-Cabello, J.C. Cartilage Regeneration in Preannealed Silk Elastin-Like Co-Recombinamers Injectable Hydrogel Embedded with Mature Chondrocytes in an Ex Vivo Culture Platform. Biomacromolecules 2018, 19, 4333-4347. [CrossRef]

180. Kaplan, D.L.; Yucel, T. Vortex-Induced Silk Fibroin Gelation for Encapsulation and Delivery. Google Patent WO2011005381A2, 13 January 2011.

181. Guziewicz, N.; Best, A.; Perez-Ramirez, B.; Kaplan, D.L. Lyophilized silk fibroin hydrogels for the sustained local delivery of therapeutic monoclonal antibodies. Biomaterials 2011, 32, 2642-2650. [CrossRef] [PubMed]

182. Foo, C.W.P.; Bini, E.; Hensman, J.; Knight, D.; Lewis, R.; Kaplan, D. Role of pH and charge on silk protein assembly in insects and spiders. Appl. Phys. A 2006, 82, 223-233. [CrossRef] 
183. Xiao, W.; He, J.; Nichol, J.W.; Wang, L.; Hutson, C.B.; Wang, B.; Du, Y.; Fan, H.; Khademhosseini, A. Synthesis and characterization of photocrosslinkable gelatin and silk fibroin interpenetrating polymer network hydrogels. Acta Biomater. 2011, 7, 2384-2393. [CrossRef] [PubMed]

184. Shang, S.; Zhu, L.; Fan, J. Intermolecular interactions between natural polysaccharides and silk fibroin protein. Carbohydr. Polym. 2013, 93, 561-573. [CrossRef] [PubMed]

185. Kim, U.-J.; Park, J.; Li, C.; Jin, H.-J.; Valluzzi, R.; Kaplan, D.L. Structure and properties of silk hydrogels. Biomacromolecules 2004, 5, 786-792. [CrossRef] [PubMed]

186. Teixeira, L.S.M.; Feijen, J.; van Blitterswijk, C.A.; Dijkstra, P.J.; Karperien, M. Enzyme-catalyzed crosslinkable hydrogels: Emerging strategies for tissue engineering. Biomaterials 2012, 33, 1281-1290. [CrossRef] [PubMed]

187. Yan, L.-P.; Silva-Correia, J.; Ribeiro, V.P.; Miranda-Gonçalves, V.; Correia, C.; da Silva Morais, A.; Sousa, R.A.; Reis, R.M.; Oliveira, A.L.; Oliveira, J.M. Tumor growth suppression induced by biomimetic silk fibroin hydrogels. Sci. Rep. 2016, 6, 31037. [CrossRef]

188. Ribeiro, V.P.; Silva-Correia, J.; Gonçalves, C.; Pina, S.; Radhouani, H.; Montonen, T.; Hyttinen, J.; Roy, A.; Oliveira, A.L.; Reis, R.L. Rapidly responsive silk fibroin hydrogels as an artificial matrix for the programmed tumor cells death. PLoS ONE 2018, 13, e0194441. [CrossRef]

189. Costa, J.B.; Silva-Correia, J.; Reis, R.L.; Oliveira, J.M. Recent advances on 3D printing of patient-specific implants for fibrocartilage tissue regeneration. J. 3D Print. Med. 2018, 2, 129-140. [CrossRef]

190. Li, L.; Yu, F.; Shi, J.; Shen, S.; Teng, H.; Yang, J.; Wang, X.; Jiang, Q. In Situ repair of bone and cartilage defects using 3D scanning and 3D printing. Sci. Rep. 2017, 7, 9416. [CrossRef]

191. Costa, J.B.; Silva-Correia, J.; Oliveira, J.M.; Reis, R.L. Fast Setting Silk Fibroin Bioink for Bioprinting of Patient-Specific Memory-Shape Implants. Adv. Healthc. Mater. 2017, 6, 1701021. [CrossRef]

192. Gladman, A.S.; Matsumoto, E.A.; Nuzzo, R.G.; Mahadevan, L.; Lewis, J.A. Biomimetic 4D printing. Nat. Mater. 2016, 15, 413. [CrossRef]

193. Sant, S.; Hancock, M.J.; Donnelly, J.P.; Iyer, D.; Khademhosseini, A. Biomimetic gradient hydrogels for tissue engineering. Can. J. Chem. Eng. 2010, 88, 899-911. [CrossRef] [PubMed]

194. Gurkan, U.A.; El Assal, R.; Yildiz, S.E.; Sung, Y.; Trachtenberg, A.J.; Kuo, W.P.; Demirci, U. Engineering anisotropic biomimetic fibrocartilage microenvironment by bioprinting mesenchymal stem cells in nanoliter gel droplets. Mol. Pharm. 2014, 11, 2151-2159. [CrossRef] [PubMed]

195. Duan, B.; Hockaday, L.A.; Kang, K.H.; Butcher, J.T. 3D bioprinting of heterogeneous aortic valve conduits with alginate/gelatin hydrogels. J. Biomed. Mater. Res. Part A 2013, 101, 1255-1264. [CrossRef] [PubMed]

196. Gaebel, R.; Ma, N.; Liu, J.; Guan, J.; Koch, L.; Klopsch, C.; Gruene, M.; Toelk, A.; Wang, W.; Mark, P. Patterning human stem cells and endothelial cells with laser printing for cardiac regeneration. Biomaterials 2011, 32, 9218-9230. [CrossRef] [PubMed]

197. Kolesky, D.B.; Truby, R.L.; Gladman, A.S.; Busbee, T.A.; Homan, K.A.; Lewis, J.A. 3D bioprinting of vascularized, heterogeneous cell-laden tissue constructs. Adv. Mater. 2014, 26, 3124-3130. [CrossRef] [PubMed]

198. Merceron, T.K.; Burt, M.; Seol, Y.-J.; Kang, H.-W.; Lee, S.J.; Yoo, J.J.; Atala, A. A 3D bioprinted complex structure for engineering the muscle-tendon unit. Biofabrication 2015, 7, 035003. [CrossRef] [PubMed]

199. Spiller, K.L.; Laurencin, S.J.; Charlton, D.; Maher, S.A.; Lowman, A.M. Superporous hydrogels for cartilage repair: Evaluation of the morphological and mechanical properties. Acta Biomater. 2008, 4, 17-25. [CrossRef] [PubMed]

200. Drury, J.L.; Dennis, R.G.; Mooney, D.J. The tensile properties of alginate hydrogels. Biomaterials 2004, 25, 3187-3199. [CrossRef] [PubMed]

201. Annabi, N.; Nichol, J.W.; Zhong, X.; Ji, C.; Koshy, S.; Khademhosseini, A.; Dehghani, F. Controlling the porosity and microarchitecture of hydrogels for tissue engineering. Tissue Eng. Part B: Rev. 2010, 16, 371-383. [CrossRef] [PubMed]

202. Lien, S.-M.; Ko, L.-Y.; Huang, T.-J. Effect of pore size on ECM secretion and cell growth in gelatin scaffold for articular cartilage tissue engineering. Acta Biomater. 2009, 5, 670-679. [CrossRef] [PubMed]

203. Carvalho, C.R.; Costa, J.B.; da Silva Morais, A.; López-Cebral, R.; Silva-Correia, J.; Reis, R.L.; Oliveira, J.M. Tunable Enzymatically Cross-Linked Silk Fibroin Tubular Conduits for Guided Tissue Regeneration. Adv. Healthc. Mater. 2018, 7, 1800186. [CrossRef] [PubMed] 
204. Canadas, R.F.; Ren, T.; Marques, A.P.; Oliveira, J.M.; Reis, R.L.; Demirci, U. Biochemical Gradients to Generate 3D Heterotypic-Like Tissues with Isotropic and Anisotropic Architectures. Adv. Funct. Mater. 2018, 28, 1804148. [CrossRef]

205. Canadas, R.F.; Ren, T.; Tocchio, A.; Marques, A.P.; Oliveira, J.M.; Reis, R.L.; Demirci, U. Tunable anisotropic networks for 3-D oriented neural tissue models. Biomaterials 2018, 181, 402-414. [CrossRef] [PubMed]

206. D'este, M.; Eglin, D. Hydrogels in calcium phosphate moldable and injectable bone substitutes: Sticky excipients or advanced 3-D carriers? Acta Biomater. 2013, 9, 5421-5430. [CrossRef] [PubMed]

207. Román, J.; Cabañas, M.V.; Pena, J.; Vallet-Regí, M. Control of the pore architecture in three-dimensional hydroxyapatite-reinforced hydrogel scaffolds. Sci. Technol. Adv. Mater. 2011, 12, 045003. [CrossRef]

208. Beşkardeş, I.G.; Demirtaş, T.T.; Durukan, M.D.; Gümüşderelioğlu, M. Microwave-assisted fabrication of chitosan-hydroxyapatite superporous hydrogel composites as bone scaffolds. J. Tissue Eng. Regen. Med. 2015, 9, 1233-1246. [CrossRef]

209. Killion, J.A.; Kehoe, S.; Geever, L.M.; Devine, D.M.; Sheehan, E.; Boyd, D.; Higginbotham, C.L. Hydrogel/bioactive glass composites for bone regeneration applications: Synthesis and characterisation. Mater. Sci. Eng. C 2013, 33, 4203-4212. [CrossRef]

210. Ma, X.; He, Z.; Han, F.; Zhong, Z.; Chen, L.; Li, B. Preparation of collagen/hydroxyapatite/alendronate hybrid hydrogels as potential scaffolds for bone regeneration. Colloids Surf. B Biointerfaces 2016, 143, 81-87. [CrossRef]

211. Alves Cardoso, D.; Van Den Beucken, J.; Both, L.; Bender, J.; Jansen, J.; Leeuwenburgh, S. Gelation and biocompatibility of injectable Alginate-Calcium phosphate gels for bone regeneration. J. Biomed. Mater. Res. Part A 2014, 102, 808-817. [CrossRef] [PubMed]

212. Jiang, J.; Tang, A.; Ateshian, G.A.; Guo, X.E.; Hung, C.T.; Lu, H.H. Bioactive stratified polymer ceramic-hydrogel scaffold for integrative osteochondral repair. Ann. Biomed. Eng. 2010, 38, 2183-2196. [CrossRef] [PubMed]

213. Ren, B.W.; Chen, X.Y.; Du, S.K.; Ma, Y.; Chen, H.A.; Yuan, G.L.; Li, J.L.; Xiong, D.S.; Tan, H.P.; Ling, Z.H.; et al. Injectable Polysaccharide Hydrogel Embedded Hydroxyapatite Calcium Carbonate Drug Delivery Bone Tissue Engineering. Int. J. Biol. Macromol. 2018, 118, 1257-1266. [CrossRef] [PubMed]

214. Li, F.Y.; Truong, V.X.; Fisch, P.; Levinson, C.; Glattauer, V.; Zenobi-Wong, M.; Thissen, H.; Forsythe, J.S.; Frith, J.E. Cartilage tissue formation through assembly of microgels containing mesenchymal stem cells. Acta Biomater. 2018, 77, 48-62. [CrossRef] [PubMed]

215. Zineh, B.R.; Shabgard, M.R.; Roshangar, L. Mechanical and biological performance of printed alginate/methylcellulose/halloysite nanotube/polyvinylidene fluoride bio-scaffolds. Mater. Sci. Eng. C-Mater. Biol. Appl. 2018, 92, 779-789. [CrossRef]

216. Kankala, R.K.; Lu, F.J.; Liu, C.G.; Zhang, S.S.; Chen, A.Z.; Wang, S.B. Effect of Icariin on Engineered 3D-Printed Porous Scaffolds for Cartilage Repair. Materials 2018, 11, 16. [CrossRef]

217. Duin, S.; Schütz, K.; Ahlfeld, T.; Lehmann, S.; Lode, A.; Ludwig, B.; Gelinsky, M. 3D Bioprinting of Functional Islets of Langerhans in an Alginate/Methylcellulose Hydrogel Blend. Adv. Healthc. Mater. 2019, 1801631. [CrossRef]

218. Zheng, A.; Cao, L.Y.; Liu, Y.; Wu, J.N.; Zeng, D.L.; Hu, L.W.; Zhang, X.K.; Jiang, X.Q. Biocompatible silk/calcium silicate/sodium alginate composite scaffolds for bone tissue engineering. Carbohydr. Polym. 2018, 199, 244-255. [CrossRef] [PubMed]

219. Asadi, N.; Alizadeh, E.; Rahmani Del Bakhshayesh, A.; Mostafavi, E.; Akbarzadeh, A.; Davaran, S. Fabrication and in Vitro Evaluation of Nanocomposite Hydrogel Scaffolds Based on Gelatin/PCL-PEG-PCL for Cartilage Tissue Engineering. ACS Omega 2019, 4, 449-457. [CrossRef]

220. Rios, P.D.; Skoumal, M.; Liu, J.; Youngblood, R.; Kniazeva, E.; Garcia, A.J.; Shea, L.D. Evaluation of encapsulating and microporous nondegradable hydrogel scaffold designs on islet engraftment in rodent models of diabetes. Biotechnol. Bioeng. 2018, 115, 2356-2364. [CrossRef] [PubMed]

221. Lih, E.; Park, W.; Park, K.W.; Chun, S.Y.; Kim, H.; Joung, Y.K.; Kwon, T.G.; Hubbell, J.A.; Han, D.K. A Bioinspired Scaffold with Anti-Inflammatory Magnesium Hydroxide and Decellularized Extracellular Matrix for Renal Tissue Regeneration. ACS Cent. Sci. 2019, 5, 458-467. [CrossRef] [PubMed]

222. Melton, J.T.K.; Wilson, A.J.; Chapman-Sheath, P.; Cossey, A.J. TruFit CB ${ }^{\circledR}$ bone plug: Chondral repair, scaffold design, surgical technique and early experiences. Expert Rev. Med Devices 2010, 7, 333-341. [CrossRef] [PubMed] 
223. Kon, E.; Delcogliano, M.; Filardo, G.; Pressato, D.; Busacca, M.; Grigolo, B.; Desando, G.; Marcacci, M. A novel nano-composite multi-layered biomaterial for treatment of osteochondral lesions: Technique note and an early stability pilot clinical trial. Injury 2010, 41, 693-701. [CrossRef] [PubMed]

224. Bioresorbable, Acellular, Biphasic Scaffold Gets EU Approval for Knee Cartilage Repair. Available online: https://www.medgadget.com/2010/02/bioresorbable_acellular_biphasic_scaffold_gets_eu_approval_ for_knee_cartilage_repair.html (accessed on 25 November 2014).

225. Gomoll, A.H. Osteochondral Allograft Transplantation Using the Chondrofix Implant. Oper. Tech. Sports Med. 2013, 21, 90-94. [CrossRef]

226. Parmaksiz, M.; Dogan, A.; Odabas, S.; Elçin, A.E.; Elçin, Y.M. Clinical applications of decellularized extracellular matrices for tissue engineering and regenerative medicine. Biomed. Mater. 2016, 11, 022003. [CrossRef] [PubMed]

227. Gerson, C.J.; Elkins, R.C.; Goldstein, S.; Heacox, A.E. Structural integrity of collagen and elastin in SynerGraft ${ }^{\circledR}$ decellularized-cryopreserved human heart valves. Cryobiology 2012, 64, 33-42. [CrossRef] [PubMed]

228. Beres, A.; Christison-Lagay, E.R.; Romao, R.L.P.; Langer, J.C. Evaluation of Surgisis for patch repair of abdominal wall defects in children. J. Pediatric Surg. 2012, 47, 917-919. [CrossRef] [PubMed]

(C) 2019 by the authors. Licensee MDPI, Basel, Switzerland. This article is an open access article distributed under the terms and conditions of the Creative Commons Attribution (CC BY) license (http://creativecommons.org/licenses/by/4.0/). 